\title{
The calcareous nannofossil crisis in Northern Spain (Asturias province) linked to the Early Toarcian warming-driven mass extinction
}

\author{
Ángela Fraguas a *, María José Comas-Rengifo a , Juan J. Gómez ${ }^{\mathrm{b}}$, Antonio Goy ${ }^{\mathrm{c}}$ \\ ${ }^{a}$ Dpto. de Paleontología, Facultad de Ciencias Geológicas, UCM, Calle José Antonio Novais 2, 28040 Madrid, Spain \\ ${ }^{\mathrm{b}}$ Dpto. de Estratigrafía, Facultad de Ciencias Geológicas (UCM) and Instituto de Geociencias (UCM-CSIC), Calle José Antonio Novais 2, 28040 Madrid, Spain

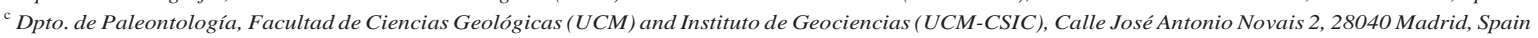

ABSTRAC

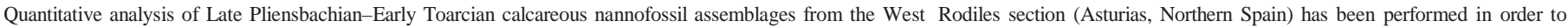

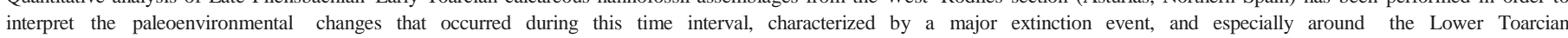

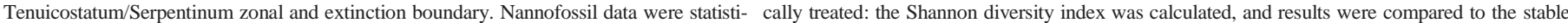

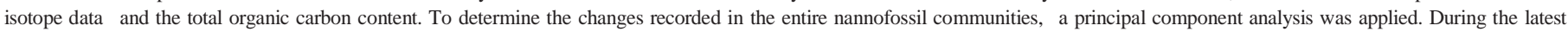

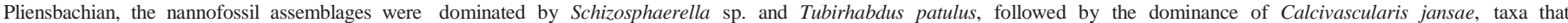

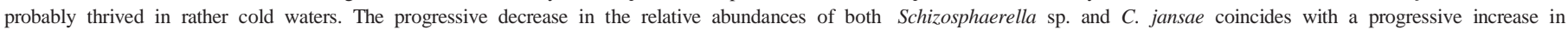

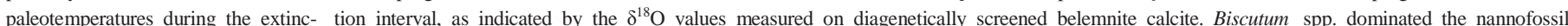

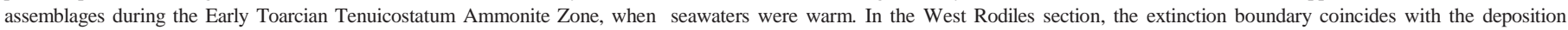

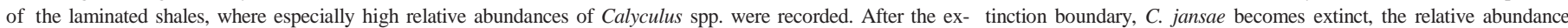

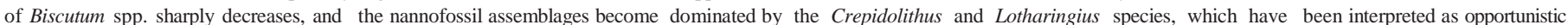

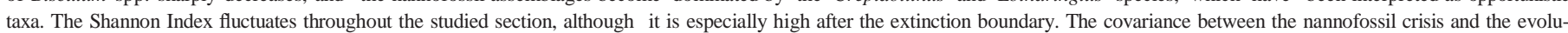

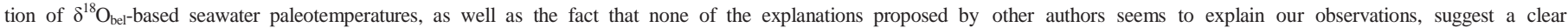

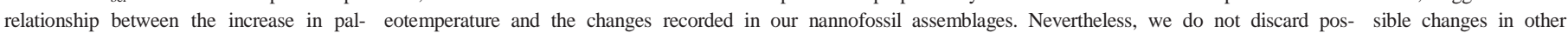
paleoenvironmental parameters related or not to warming.

Keywords:

Calcareous nannofossils Biotic crisis

Extinction event Climate change Early Toarcian Asturias

\section{Introduction}

The Early Toarcian has often been described as an interval during which important changes in temperatures took place (e.g. Sælen et al., 1996; Jenkyns, 2003; Rosales et al., 2004; Gómez et al., 2008; Metodiev and KolevaRekalova, 2008; Suan et al., 2008; Dera et al., 2009; Gómez and Arias, 2010; Gómez and Goy, 2010, 2011; Suan et al., 2010; García Joral et al., 2011), coinciding with a significant trans- gressive peak (e.g. Hallam, 1961, 1981, 1997; Hallam and Wignall, 1999; Gómez and Goy, 2000, 2005; Gómez et al., 2008; Suan et al., 2008; Gómez and Arias, 2010; Suan et al., 2010). In the here studied West Rodiles section (Northern Spain) (Fig. 1) a progressive seawater warming, based on oxygen isotope values obtained from belemnite

\footnotetext{
* Corresponding author. Tel.: +34913944877; fax:+34913944849. E-mailaddresses:arfragua@geo.ucm.es(Á.Fraguas),mjcomas@geo.ucm.es (M.J. Comas-Rengifo), jgomez@geo.ucm.es (J.J. Gómez), angoy@geo.ucm.es (A. Goy).
}

calcite $\left(\delta^{18} \mathrm{O}_{\text {bel }}\right)$, was recorded during the latest Pliensbachian-earliest Toarcian. It was followed by a pronounced increase in temperature of about $6{ }^{\circ} \mathrm{C}$ around the Tenuicostatum/Serpentinum Ammonite Zones (AZs) boundary, reaching an average seawater paleotemperature of $21^{\circ} \mathrm{C}$ (Gómez et al., 2008).

During the Early Toarcian, major perturbations in the global carbon cycle have been inferred for different sub-basins, based on the presence of a pronounced negative Carbon isotope excursion (CIE) recorded in bulk rock carbonate, carbonate microfractions, marine organic matter, brachiopod calcite and continental fossil wood (e.g. Küspert, 1982; Jenkyns and Clayton, 1986; Jiménez et al., 1996; Hesselbo et al., 2000; Schouten et al., 2000; Röhl et al., 2001; Schmid-Röhl et al., 2002; van Breugel et al., 2006; Hesselbo et al., 2007; Gómez et al., 2008; Suan et al., 2008, 2010; Hermoso et al., 2009; Caruthers et al., 2010; Izumi and Tanabe, 2010; Littler et al., 2010; Hesselbo and Pieñkowski, 2011), but this excursion has not been clearly recorded in belemnite calcite (McArthur et al., 2000; van de Schootbrugge et al., 2005; 
Wignall et al., 2005; McArthur, 2007; McArthur et al., 2007; Gómez et al., 2008; Gómez and Arias, 2010; Gómez and Goy, 2011).

Several authors have interpreted this negative CIE as the result of a massive release of large quantities of isotopically light methane from the dissociation of gas hydrates buried in marine sediments (Hesselbo et al., 2000; Beerling et al., 2002; Cohen et al., 2004; Kemp et al., 2005; Hesselbo et al., 2007), but this hypothesis has been challenged by Beerling and Brentnall (2007). Some other papers support that the neg- ative CIE is a consequence of the thermal metamorphism of carbon-rich sediments in the Karoo-Ferrar large igneous province (LIP) (McElwain et al., 2005; Svensen et al., 2007), but this last hypothesis has also been dismissed by Summons et al. (2008) and Gröcke et al. (2009).

Another important event that took place during the Early Toarcian was a mass extinction event, which affected many different groups of marine organisms over a wide geographic area, including ammonites from both the Boreal and the Tethyan domains (Little and Benton, 1995; Macchioni, 2002; Cecca and Macchioni, 2004; Bilotta et al., 2010; Dera et al., 2010); brachiopods from Central Spain (García- Joral and Goy, 2009; García Joral et al., 2011) and the UK (Little and Benton, 1995; Harries and Little, 1999); benthic foraminifera and os- tracods from Central Spain (Arias et al., 1992; Arias, 2009; Gómez and Arias, 2010), UK (Little and Benton, 1995; Hallam, 1997; Harries and Little, 1999; Wignall, 2001; Wignall et al., 2005), Italy (Nocchi and Bartolini, 1994), France and NW Europe (Bassoullet and Baudin, 1994; Hylton and Hart, 2000; Hart et al., 2010), Portugal (Boomer et al., 1998) and Morocco (Bassoullet et al., 1991). Concomitant with the mass extinction, calcareous nannofossil assemblages experi- enced a drastic decrease in abundance of both Schizosphaerella (Bucefalo Palliani et al., 1998, 2002; Mattioli and Pittet, 2002; Erba, 2004; Mattioli and Pittet, 2004; Mattioli et al., 2004b; Tremolada et al., 2005; van de Schootbrugge et al., 2005; Mattioli et al., 2008; Suan et al., 2008; Mattioli et al., 2009) and Calcivascularis jansae

( ${ }^{(*)}$ See the appendix), which subsequently became extinct

(Bucefalo Palliani and Mattioli, 1995; Bucefalo Palliani et al., 1998; Tremolada et al., 2005; Mattioli et al., 2008).

During the last two decades, the anoxia linked to the postulated Early Toarcian oceanic anoxic event (ETOAE), defined by Jenkyns (1988), have been inferred as the main cause of the mass extinction (e.g. Jenkyns, 1988; Bassoullet and Baudin, 1994; Nikitenko and Shurygin, 1994; Little and Benton, 1995; Harries and Little, 1999; Hesselbo et al., 2000; Hylton and Hart, 2000; Pálfy and Smith, 2000; Guex et al., 2001; Bucefalo Palliani et al., 2002; Macchioni, 2002; Vörös, 2002; Aberhan and Baumiller, 2003; Mattioli et al., 2004b; Tremolada et al., 2005; Wignall et al., 2005; Mailliot et al., 2006, 2009; Pearce et al., 2006; Mattioli et al., 2008, 2009; Bilotta et al., 2010; Hart et al., 2010). However, deposition of real black shales containing

$>5$ wt.\% total organic carbon (TOC) (Bates and Jackson, 1987; Kearey, 2001; McArthur et al., 2008) is mainly restricted to the Northwestern Europe Euxinic Basin (WEEB) (Gómez and Goy, 2011). Conversely, the time equivalent deposits in most European and Northern African sections are bioturbated, indicating well oxygenated conditions (Ruget, 1985; Alméras and Elmi, 1993; Arias, 2006, 2007). To indicate the event that generated the presence of the Early to Middle Toarcian black shale facies in the WEEB, the more appropriated name of Regional Anoxic Event (RAE) has been proposed by McArthur (2007) and McArthur et al. (2007). On the contrary, the Early Toarcian mass extinction has generally been considered a synchronous and global event, which has also been recorded in numerous areas showing evidences of well oxygenated bottom waters, where black shale deposits are absent (Arias et al., 1992; Monaco, 1995; Gómez, 2002a,b; Goy et al., 2006; Gómez et al., 2008; Arias, 2009; Gómez and Arias, 2010; Gómez and Goy, 2010, 2011; Rodríguez- Tovar and Uchman, 2010). Hence, a direct cause and effect relation- ship between the Early Toarcian anoxia and the mass extinction has not been established and, in fact, the main phase of deposition of black shales in the WEEB does not coincide with the extinction interval, but mainly with the repopulation interval (see below). Instead, on the basis of the strong covariance between the timing and patterns of the Early Toarcian mass extinction and the seawater paleotemperatures estimated, a warming event, probably of global extent, has recently been proposed as the main factor responsible for mass extinction (Gómez et al., 2008; García-Joral and Goy, 2009; Gómez and Arias, 2010; Gómez and Goy, 2010, 2011; García Joral et al., 2011).

Three main phases were distinguished by Kauffman and Erwin (1995) in mass extinction events, on the basis of the relation between extinction (E) and origination (O) rates: 1) the extinction interval, 2) the extinction boundary and 3 ) the repopulation interval, which in- cludes the survival and the recovery intervals. During the extinction in- terval, $\mathrm{E}$ is higher than $\mathrm{O}$ and the diversity of the community decreases drastically. At the extinction boundary, E reaches the highest value and $\mathrm{O}$ shows a minimum. Finally, during the repopulation interval, $\mathrm{O}$ progressively increases with respect to $\mathrm{E}$, and the assemblages are domi- nated by surviving taxa and newly evolved species. In this work, the extinction interval includes the uppermost Spinatum AZ of the Upper Pliensbachian and the Tenuicostatum AZ of the Lower Toarcian, and the extinction boundary is located around the Tenuicostatum/ Serpentinum (=Falciferum) AZs boundary, as several authors pointed out (e.g. Arias et al., 1992; Little and Benton, 1995; Harries and Little, 1999; Cecca and Macchioni, 2004; Wignall et al., 2005; Gómez et al., 2008; Gómez and Arias, 2010; Gómez and Goy, 2010; García Joral et al., 2011). The repopulation interval starts above the extinction boundary and extends beyond the top of the studied part of the section. The West Rodiles section provides a continuous and superbly ex- posed Upper Pliensbachian-Lower Toarcian sedimentary succession, well-calibrated to the standard ammonite zones and subzones (ASzs) and with good preservation of coccoliths. Moreover, the work of Gómez et al. (2008) presents detailed isotopic, TOC, and stratigraphic data for the studied section; some additional new isoto- pic data are presented here. The aim of this study is to determine the response of calcareous nannofossils to the paleoenvironmental changes that occurred in the West Rodiles section (Asturias, N Spain) during the Late Pliensbachian-Early Toarcian time interval, with special emphasis on the Early Toarcian mass extinction event. For this purpose, the abundance and diversity of nannofossils were quantified, treated by statistical analysis, and compared with the paleoenvironmental changes revealed by geochemical data.

\section{Materialsandmethods}

\subsection{Location and lithostratigraphy of the West Rodiles section}

The West Rodiles section ( $5^{\circ} 22^{\prime} 31^{\prime \prime} \mathrm{W} ; 43^{\circ} 32^{\prime} 27^{\prime \prime} \mathrm{N}$ ) crops out in a coastal cliff on the west side of the Punta de Rodiles (Fig. 1), in Eastern Asturias (Northern Spain). This section belongs to the Jurassic succes- sion of Asturias, which is formed of two depositional megasequences separated by an unconformity related to extensional tectonic pulses (Borrego et al., 1996). The lower megasequence, the Villaviciosa Group (Valenzuela, 1988), is mainly calcareous, and ranges in age from Hettangian to Lower Bajocian. It includes the Gijón and the Rodiles formations. The upper megasequence, the Ribadesella Group, is Upper Jurassic in age, and is mainly composed of siliciclastics (Valenzuela, 1988). The samples analyzed in this study belong to the Santa Mera Member of the Rodiles Formation that is characterized by an alternation of limestone and marl. These sediments are thought to have been de- posited on a carbonate ramp at varying depths, generally below the storm wave base (Valenzuela et al., 1986).

The continuous and well-dated West Rodiles section, spans from the Upper Pliensbachian Apyrenum ASz (Spinatum AZ) to the Lower Toarcian Falciferum ASz (Serpentinum AZ) and is made up of a $14 \mathrm{~m}$ thick alternation of marls and limestones with a one-meter thick inter- calation of laminated calcareous marls, which coincides with a 


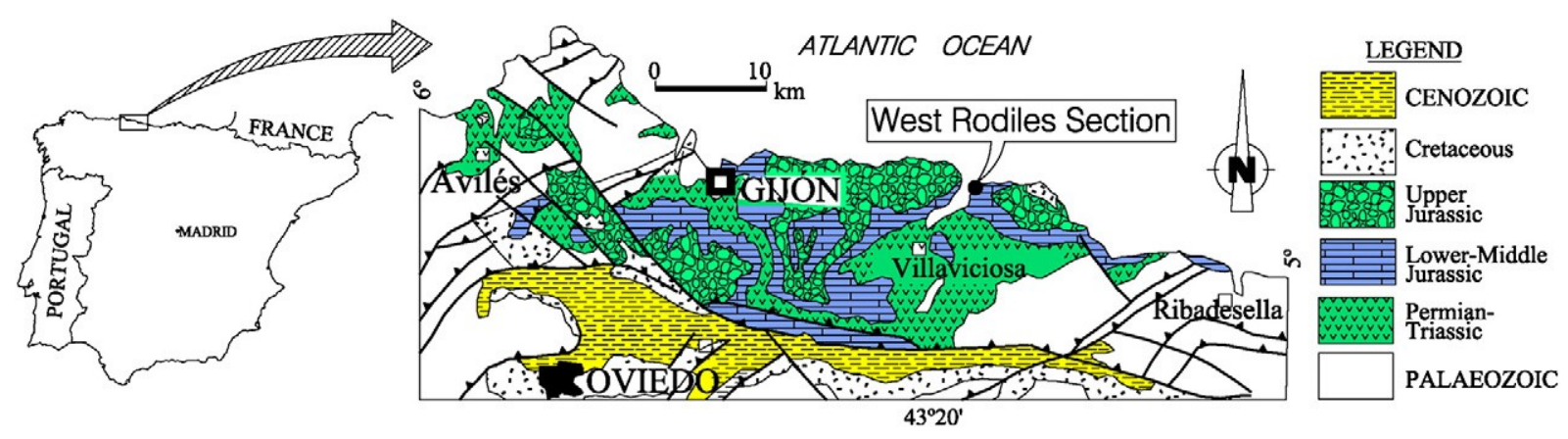

Fig. 1. Geological map of North-Eastern Asturias, showing the location of the West Rodiles section.

transgressive peak (Cycle LJ3-2 of Gómez and Goy, 2005) and a negative CIE recorded in bulk carbonate, but not in belemnite calcite (Gómez et al., 2008) (Fig. 2).

\subsection{Samples treatment and statistical analyses}

A total of 34 samples of marls were collected for this study and, based on high-resolution ammonite biostratigraphy (Gómez et al., 2008), 14 of these samples were from the Spinatum AZ, 8 from the Ten- uicostatum AZ and 12 from the Serpentinum AZ. In terms of calcareous nannofossils (Fraguas and Young, 2011), 20 samples belong to the NJ5 Lotharingius hauffii calcareous nannofossil zone (CNZ) and 14 to the NJ6 Carinolithus superbus CNZ (Fig. 2).

The corresponding smear slides were prepared following the ran- dom settling technique described by Geisen et al. (1999), for quantifying the absolute abundances of specimens (coccoliths and the nannolith Schizosphaerella) per gram of rock. Briefly, a small quantity of dried rock-powder (30 and $35 \mathrm{mg}$ ) is mixed with water (oversaturated with respect to $\mathrm{CaCO}_{3}$ and with a basic $\mathrm{pH}$ ) in a homo- geneous suspension and left to settle for $24 \mathrm{~h}$ on a cover slip in a set- tling device. The cover slip is then recovered, dried and attached to a microscope slide.

In each smear slide, 300 nannofossils were counted using a Leica DMLP microscope, at $1250 \times$ magnification. All the specimens counted in this work are well to moderately preserved (Fig. 2), although some of them show a slight degree of etching and overgrowth, mainly along their edges.

The relative abundances of the species identified were calculated as percentages. The percentage of each coccolith species was estimated with respect to the total number of coccoliths, and the percentage of Schizosphaerella sp. was calculated with respect to the total nannofossil

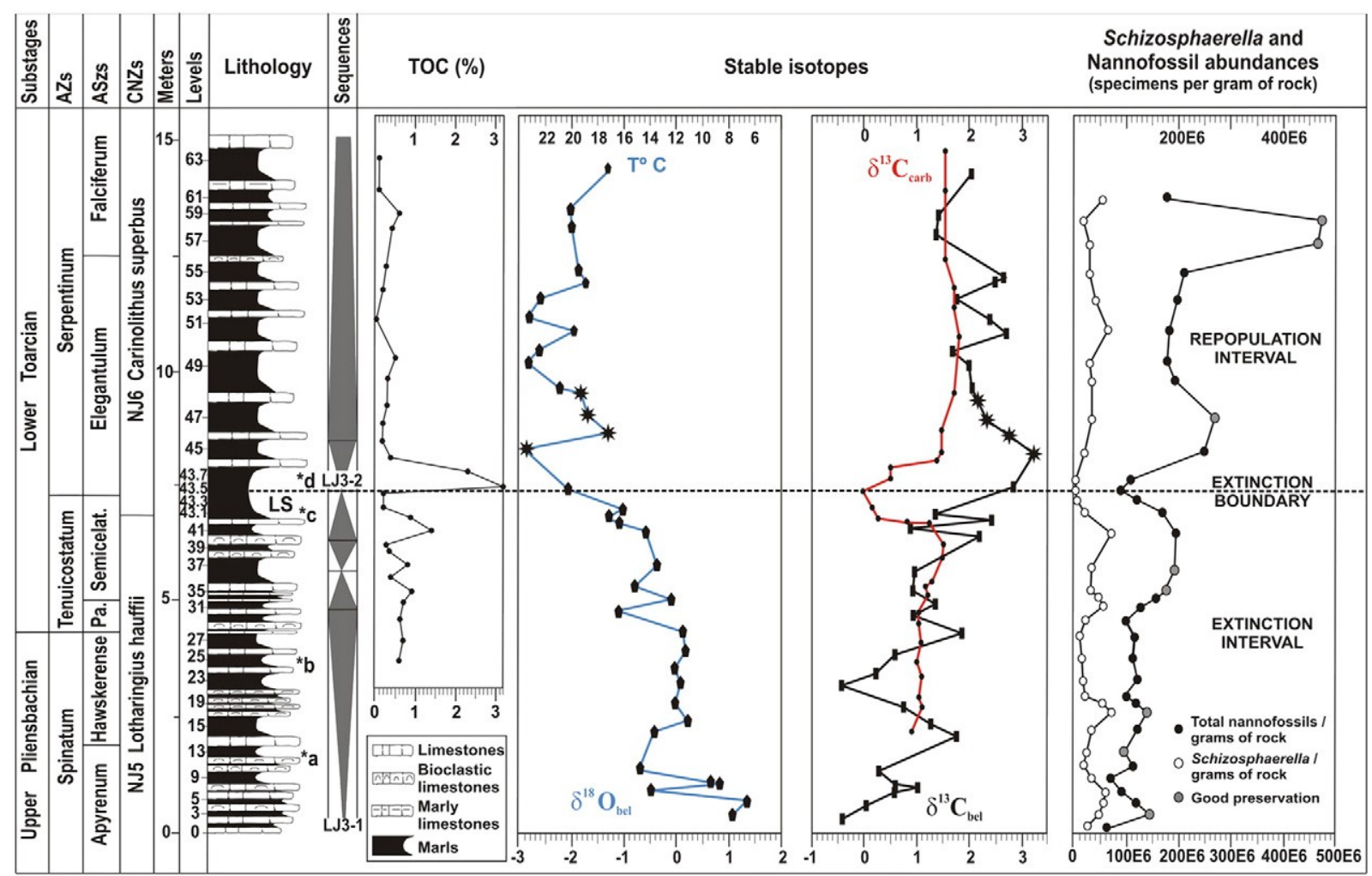

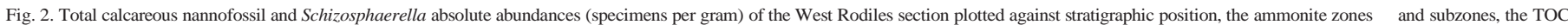

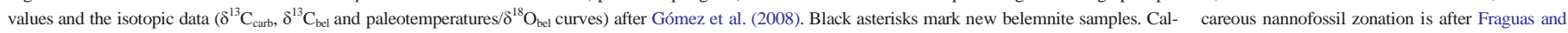

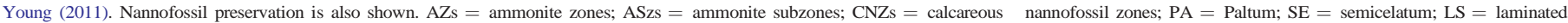
shales; ${ }^{*} \mathrm{a}=\mathrm{FO}$ of Lotharingius sigillatus; $* \mathrm{~b}=\mathrm{FO}$ of Lotharingius crucicentralis; ${ }^{*} \mathrm{c}=\mathrm{FO}$ of Carinolithus superbus;

$* \mathrm{~d}=\mathrm{LO}$ of Calcivascularis jansae. 
content. Principal component analysis (PCA) was performed on the nannofossil assemblages with the PAST software. This type of analysis allows determining the changes recorded in the entire nannofossil com- munity, instead of variation in single species abundance.

Due to the presumably different biological affinities of the extinct coccoliths and Schizosphaerella, only the relative abundances of coccoliths were introduced in the PCA. Only taxa with mean relative abun- dances $>2 \%$ (13 of the 30 species identified in the samples) were used for the analysis. Some taxa such as Crepidolithus cavus and Crepidolithus granulatus or Biscutum finchii (=Similiscutum finchii sensu de Kaenel and Bergen, 1993) and Biscutum novum (=Similiscutum novum sensu Mattioli et al., 2004a) were grouped, since they present abundance peaks in the samesamples.

We also calculated the Shannon Index (H), a mathematical mea- sure of species diversity in a community (Shannon and Weaver, 1949), as follows:

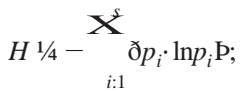

where $i$ is a species, $s$ is the number of species identified, and $p_{i}$ is the relative abundance of each species.

\subsection{Stable isotope and total organic carbon analysis}

A total of 37 belemnite guards were prepared and analyzed for stable isotopes, aimed to obtain the primary Late Pliensbachian- Early Toarcian seawater stable isotope signal. Additionally, 30 bulk carbonate samples were collected and analyzed for $\mathrm{C}$ and $\mathrm{O}$ isotopes, and 28 samples were analyzed for TOC content. The results obtained from these analyses, with the exception of four new belemnite sam- ples (Fig. 2), were previously presented and discussed by Gómez et al. (2008).

For the assessment of possible burial diagenetic alteration of the col- lected belemnites, polished samples and thick sections of each belem- nite rostrum were prepared. The thick sections were studied under the petrographic and the cathodoluminescence microscopes, and only the non-luminescent portions of the belemnite guards were sampled using a microscope-mounted dental drill. Sampling of the luminescent parts such as the apical line and the outer phragmocone wall, fractures, stylolites and borings has been avoided. All the belemnite and bulk rock samples included in Gómez et al. (2008) were processed at Michigan University (USA), and the four new belemnite samples presented in this work were analyzed at Salamanca University (Spain).

For stable isotope analysis, carbonate samples weighing a minimum of 10 micrograms were placed in stainless steel boats. Samples were roasted at 200 ${ }^{\circ} \mathrm{C}$ in vacuum for one hour to remove volatile contami- nants and water. Samples were then placed in individual borosilicate reaction vessels, and reacted at $77^{\circ} \pm 1^{\circ} \mathrm{C}$ with 3 or 4 drops of anhy- drous phosphoric acid for $8 \mathrm{~min}$ in a Finnigan MAT Kiel IV preparation device coupled directly to the inlet of a Finnigan MAT 253 triple collec- tor isotope ratio mass spectrometer. $\mathrm{O}^{18}$ data are corrected for acid frac- tionation and source mixing by calibration to a best-fit regression line defined by two NBS standards, NBS 18 and NBS 19. Precision and ac- curacy of data were monitored through daily analysis of powdered carbonate standards. At least six standards were analyzed daily, bracketing the sample suite at the beginning, middle, and end of the day's run. In all samples, isotope ratios are reported in per mil relative to the standard Peedee belemnite (PDB). In both laborato- ries, reproducibility was better than 0.4\% PDB for $\delta^{13} \mathrm{C}$ and better than 0.6\% PDB for $\delta^{18} \mathrm{O}$. Internal analytical precision in belemnite carbonates was $\pm 0.04 \%$ for both $\delta^{13} \mathrm{C}$ and $\delta^{18} \mathrm{O}$, and internal analyt- ical precision in bulk carbonates was $\pm 0.04 \%$ for $\delta^{13} \mathrm{C}$ and \pm $0.09 \%$ for $\delta^{18} \mathrm{O}$.

The Late Pliensbachian-Early Toarcian seawater paleotemperature recorded in the belemnite rostra has been calculated using the
Anderson and Arthur (1983) equation: $\mathrm{T}\left({ }^{\circ} \mathrm{C}\right)=16.0-4.14\left(\delta_{\mathrm{c}}-\delta_{\mathrm{w}}\right)+$

$0.13\left(\delta_{\mathrm{c}}-\delta_{\mathrm{w}}\right)^{2}$ where $\delta_{\mathrm{c}}=\delta^{18} \mathrm{O}$ PDB is the composition of the sample, and $\delta_{\mathrm{w}}=$ $\delta^{18} \mathrm{O}$ SMOW is the composition of ambient seawater. Normal values of $\mathrm{S}=$ $34.3 \%$ for the marine salinity (Wright, 1987) and $\delta_{w}$ values of $-1 \%$ for a non-glacial ocean water (Shackleton and Kennet, 1975), were used. For paleotemperature calculation, it has been as- sumed that the $\delta^{18} \mathrm{O}$ values and, consequently, the resultant curve, es-

sentially reflects changes in environmental parameters (Sælen et al., 1996; McArthur et al., 2007; Price et al., 2009; Rexfort and Mutterlose, 2009), as the sampled non-luminescent biogenic calcite of the studied belemnite rostra precipitated in equilibrium with the seawater. It was also assumed that the biogenic calcite retains the primary isotopic com- position of the seawater and that the sampling bias, vital effects, skeletal growth and belemnite migration are not the main factors responsible for the obtained variations (Sælen et al., 1996; McArthur et al., 2007)

TOC analyses have been performed in the Centro de Espectrometría Atómica of the Universidad Complutense of Madrid using a Shimadzu TOC-V analyzer was solid samples (SSM-5000 A). One sample of stan- dard NIST 1944 analyzed every four samples of rock to control the total carbon values and bicarbonate of soda for the inorganic carbon. Analytical error was better than \pm $0.7 \%$.

\section{Results}

\subsection{Biostratigraphy}

At West Rodiles, two calcareous nannofossil zones, the NJ5 L. hauffii CNZ and the NJ6 C. superbus CNZ have been identified and calibrated to the ammonite zonation of Gómez et al. (2008). Moreover, the first oc- currence (FO) of Lotharingius sigillatus has been recognized in the upper- most levels of the Apyrenum ASz (Spinatum AZ), within the NJ5 CNZ. The FO of Lotharingius crucicentralis is observed in the Hawskerense ASz (Spinatum AZ), within the NJ5 CNZ. According to the literature (Bown and Cooper, 1998; Mattioli and Erba, 1999; Perilli et al., 2004), the boundary between the NJ5 and NJ6 CNZs is defined by the $\mathrm{FO}$ of $C$. superbus, which in the studied section has been located in the Semi- celatum ASz (Tenuicostatum AZ). Slightly above the Tenuicostatum/ Serpentinum AZs boundary, within the NJ6 CNZ, the last occurrence (LO) of C. jansae has been recorded (Figs. 2 and 3).

\subsection{Geochemical data}

The carbon isotope values obtained from bulk calcite $\left(\delta^{13} \mathrm{C}_{\text {carb }}\right)$, the carbon isotope values obtained from belemnite calcite $\left(\delta^{13} \mathrm{C}_{\text {bel }}\right)$, the $\delta^{18} \mathrm{O}_{\text {bel }}$ curve, and the wt.\% TOC values for the West Rodiles section are shown in Fig. 2. Samples used in the nannofossils study performed in this work were taken from the same stratigraphic levels as those depicted in Gómez et al. (2008), allowing a direct comparison between the geochemical data and the results obtained from the quantitative

analyses in nannofossils. During the Late Pliensbachian-Early Toarcian time interval, most of the recorded TOC (wt.\%) values are b1 wt.\%. The

highest TOC values, ranging from 1.4 to $3.2 \mathrm{wt} . \%$, are found around the Tenuicostatum/Serpentinum AZs boundary, within the $1 \mathrm{~m}$ thick lami- nated interval. The $\delta^{13} \mathrm{C}_{\text {carb }}$ curve obtained from bulk carbonate shows a $1.5 \%$ negative excursion recorded around the Tenuicostatum/ Serpentinum AZs boundary, coinciding with the occurrence of the lam- inated facies. However, this negative $\delta^{13} \mathrm{C}$ shift has not been recorded in the calcite of the belemnite rostra. The $\delta^{13} \mathrm{C}_{\text {bel }}$ curve shows an increase in values during the Semicelatum, Elegantulum and early Falciferum ASzs. The peak value (3.2\%) is recorded in belemnites of the Elegantulum ASz, slightly above the laminated interval, defining a positive $\delta^{13} \mathrm{C}$ excursion. The $\delta^{18} \mathrm{O}_{\text {bel }}$ curve shows a progressive decrease in the oxygen isotope values in the uppermost Pliensbachian and the low- ermost Toarcian, and a noteworthy excursion towards more negative values above the Tenuicostatum/Serpentinum AZs boundary reaching three peak values of about 2.9\% in the Elegantulum ASz. 


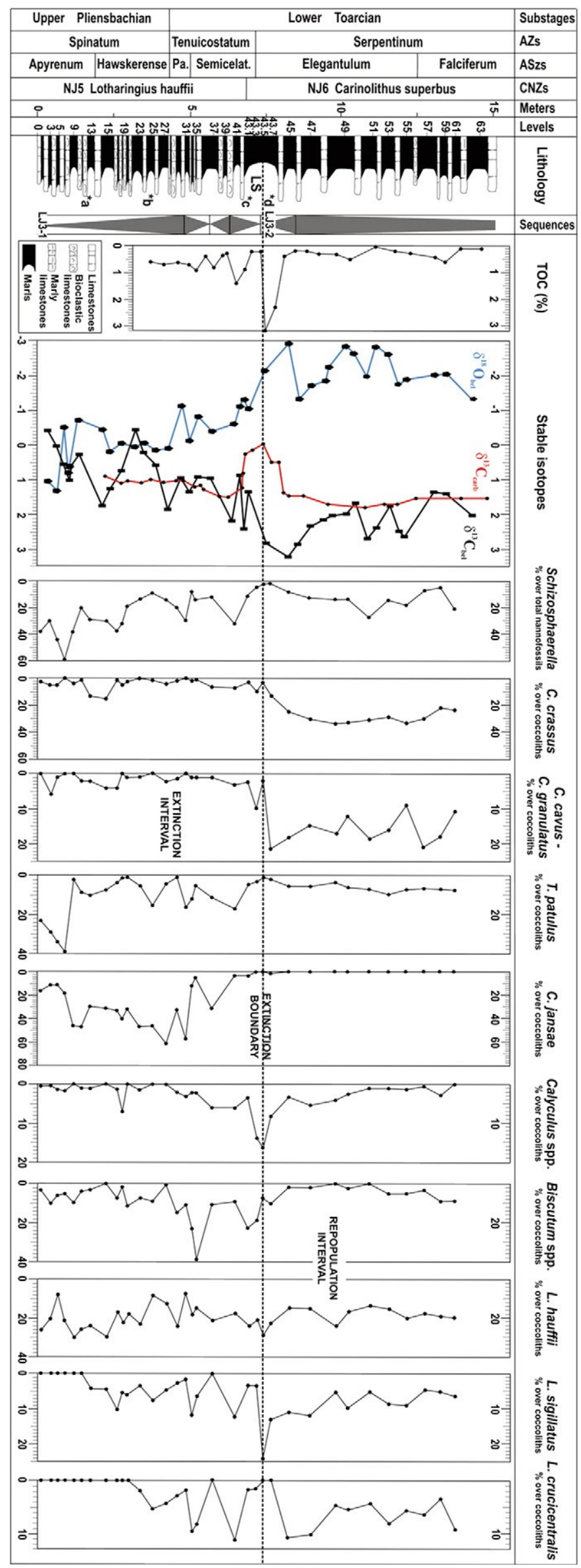

\subsection{Absolute abundances of nannofossils}

At West Rodiles, calcareous nannofossil abundance varies between 60 and 471 millions of specimens per gram of rock (Fig. 2), and show a clear increasing trend from the base to the top of the section. Nannofossil quantities are low at the base of the succession, below the

extinction interval (b150 millions of specimens per gram of rock;

from 0 to $4 \mathrm{~m}$ ). An increase of absolute abundance is observed in the lowermost levels corresponding to the extinction interval (up to 190 millions of specimens per gram; from 4 to $7 \mathrm{~m}$ ). However, around the extinction boundary, coinciding with the negative CIE and with a rapid decrease in $\delta^{18} \mathrm{O}_{\text {bel }}$ values, nannofossil abundances decrease dra-

matically (b120 millions of specimens per gram; from 7 to $8 \mathrm{~m}$ ). A sig-

nificant increase of abundance is shown during the repopulation interval, above the $\delta^{13} \mathrm{C}_{\text {carb }}$ excursion, reaching the maximum abun- dance value in the uppermost part of the section ( $>464$ millions of specimens per gram of rock; from 12 to $14 \mathrm{~m}$ ), within the Falciferum ASz, coinciding with the major decrease in $\delta^{18} \mathrm{O}_{\text {bel }}$ values.

The absolute abundance of Schizosphaerella ranges from 2 to 71 mil- lions of specimens per gram (Fig. 2). The minimum absolute abundance values occur around the extinction boundary, coinciding with the neg- ative CIE and with a rapid decrease in $\delta^{18} \mathrm{O}_{\text {bel }}$ values. A slight increase of absolute abundance of Schizosphaerella is shown during the repopulation interval, coinciding with a shift to low $\delta^{18} \mathrm{O}_{\text {bel }}$ values.

\subsection{Relative abundances}

Quantitative analyses reveal that thirteen taxa (Schizosphaerella sp., Crepidolithus crassus, C. cavus, C. granulatus, T. patulus, C. jansae, Calyculus spp., B. novum, B. finchii, Biscutum grande, L. hauffii, L. sigillatus and $L$. crucicentralis) account for more than $80 \%$ of the total calcareous nannofossil assemblages. During the latest Pliensbachian-earliest Toarcian time interval, before the extinction boundary, nannofossil as- semblages were first dominated by Schizosphaerella sp. and T. patulus, followed by the dominance of $C$. jansae and, finally, Biscutum spp. be- came the most abundant taxa. A progressive decrease in the relative abundances of Schizosphaerella sp. and $C$. jansae has been recorded dur- ing the extinction interval, i.e. minimum abundances coincide with neg- ative $\delta^{18} \mathrm{O}_{\text {bel }}$ values, the highest TOC values and the negative CIE (Fig. 3). Conversely, a peak in the relative abundances of Calyculus spp. and

L. sigillatus has been recorded around the extinction boundary. At this boundary, the species $C$. jansae becomes extinct, and the relative abun- dances of Calyculus spp. and Biscutum spp. sharply decrease. The nannofossil assemblages are dominated by $C$. crassus, which is the most abundant species of the genus Crepidolithus. After the extinction boundary, Crepidolithus taxa notably increase their relative abundance, coinciding with the major decrease in $\delta^{18} \mathrm{O}_{\text {bel }}$ values. The genus Lotharingius shows important fluctuations throughout the studied in- terval, and the first occurrences of some of the taxa correspond to the initial warming (Fig. 3).

\subsection{PCA and Shannon Index}

In the West Rodiles section, three main factors, representing more than $83 \%$ of the total variance, were extracted by PCA (Fig. 4). Only species having a loading higher than \pm 0.5 on one of the extracted factors are mentioned in the following sections. Factors are consid- ered as significant when they have a contribution to the total variance higher than $13 \%$. The first factor explains $40.6 \%$ of the total variance,

Fig. 3. Relative abundances (\%) of the most abundant nannofossil species and genera in the West Rodiles section plotted against stratigraphic position, the ammonite zones and subzones, the TOC values and the isotopic data $\left(\delta^{13} \mathrm{C}_{\text {carb }}, \delta^{13} \mathrm{C}_{\text {bel }}\right.$ and $\delta^{18} \mathrm{O}_{\text {bel }}$ curves $)$ after Gómez et al. (2008). Calcareous nannofossil zonation is after

Fraguas and Young (2011). *a $=$ FO of Lotharingius sigillatus; *b = FO of Lotharingius crucicentralis; ${ }^{*} \mathrm{c}=\mathrm{FO}$ of Carinolithus superbus; *d = LO of Calcivascularis jansae. 

and displays a significant loading of C. crassus and, to a minor extent,

C. granulatus and C. cavus (positive values) in opposition to C. jansae (negative values). The second factor contributes for $28.9 \%$, and shows Calyculus spp. and L. crucicentralis (positive values) opposed to $L$. hauffii (negative values). The third factor has a variance contribu- tion of $13.6 \%$, Biscutum spp. have a positive contribution, whereas

C. jansae and C. crassus load negatively.

PCA scores and Shannon diversity $(\mathrm{H})$ have been plotted together with factor loadings and $\delta^{13} \mathrm{C}_{\text {carb }}$ and $\delta^{18} \mathrm{O}_{\text {bel }}$ curves in Fig. 5. The Shannon diversity Index is especially high around the negative CIE and after the extinction boundary, although it significantly fluctuates throughout the studied section. The first PCA factor shows a progres- sive increase before the extinction boundary. The second PCA factor displays fluctuations and shows higher values during the extinction interval. The third factor shows a sharp increase in its values during the Tenuicostatum AZ, partly coincident with the extinction interval.

\section{Discussion}

\subsection{Calcareous nannofossil paleoecological affinities}

The paleoecological affinities of Early Jurassic calcareous nannofossils are still not well ascertained and different hypotheses have been pro- posed during the last two decades (e.g. Bown, 1987; Bucefalo Palliani and Mattioli, 1995; Claps et al., 1995; Mattioli, 1997; Bown and Cooper, 1998; Cobianchi and Picotti, 2001; Walsworth-Bell, 2001; Bucefalo Palliani et al., 2002; Erba, 2004; Mattioli and Pittet, 2004; Tremolada et al., 2005; Bour et al., 2007; Mattioli et al., 2008; Mailliot et al., 2009; Reggiani et al., 2010). In this context, the influence of paleoenvironmental conditions on the Early Jurassic nannofossil assemblages needs to be fur- ther investigated.

Early Jurassic nannofloras are constituted by coccoliths and the nannolith Schizosphaerella. The paleoecological affinities of Schizosphaerella sp. are still under debate. Several authors pro- posed that this taxon flourished under oligotrophic conditions in the surface waters (e.g. Cobianchi and Picotti, 2001; Pittet and Mattioli, 2002; Bour et al., 2007; Aguado et al., 2008; Mailliot et al., 2009; Reggiani et al., 2010), considering that it probably inhabited the shallowest part of the water column. However, Mattioli (1997), Walsworth-Bell (2001) and Mattioli and Pittet (2004), interpreted Schizosphaerella sp. as a taxon flourishing dur- ing sporadic inputs of nutrients related to unstable conditions in surface waters, recorded while carbonate-rich sediments were de- posited in proximal settings. Finally, Claps et al. (1995), Erba (2004) and Tremolada et al. (2005) argued that Schizosphaerella sp. was a deepdwelling taxon, with similar affinities as the mod- ern coccolithophore Florisphaera profunda (Molfino and McIntyre, 1990), and flourished when the nutricline was deep and surface

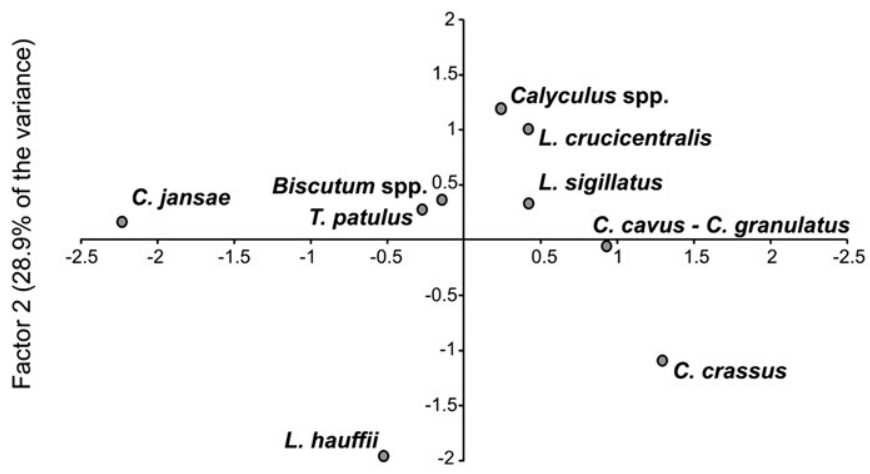

Factor $1(40.6 \%$ of the variance) waters were characterized by enhanced oligotrophy. Conversely, Mattioli and Pittet (2004) and Reggiani et al. (2010) proposed that it preferentially inhabited the shallowest part of the water column.

With respect to the coccoliths identified in this work, Bucefalo Palliani and Mattioli (1995) and Mattioli and Pittet (2004) interpreted Mitrolithus jansae (here named C. jansae, ${ }^{(*)}$ see appendix for taxonom- ical explanation) as a deep-dwelling species, taking into account the ul- trastructure and relationships of this nannolith with sea level fluctuations. However, Erba (2004) and Tremolada et al. (2005) suggested that it was an intermediate-dwelling taxon, since it slightly increases in abundance preceding black shales deposition, indicating a rise in the nutricline probably due to the input of nutrients from the continent. Bown (1987), Bown and Cooper (1998), Bucefalo Palliani et al. (2002) and Mattioli et al. (2008) found high relative abundances of $C$. jansae in the SW margin of the Tethyan Domain.

Walsworth-Bell (2001) suggested that C. crassus was an opportun- ist species, considering its high relative abundance in the carbonate- rich or "light" marlstones, representing more than $50 \%$ of the nannofossil assemblages. Mattioli and Pittet (2004) proposed that, similarly to Schizosphaerella, this taxon proliferated under unstable con- ditions in surface waters linked to storm events while carbonate-rich sediments were deposited. Recent studies support that $C$. crassus was a deep dweller (Bour et al., 2007; Mattioli et al., 2008) that probably competed with C. jansae, because light intensity is a limiting factor in the lower photic zone. However, Aguado et al. (2008) suggested that

C. crassus probably flourished under oligotrophic and stable conditions of the surface waters, and was associated with a deep nutricline. Mattioli et al. (2008) observed higher abundances of $C$. crassus along the NW margin of

Tethys. Reggiani et al. (2010) proposed that the ro- bust coccoliths of the species $C$. crassus, would tend to refract light into the cell, and that this taxon was able to live deeper than other taxa. Bucefalo Palliani and Mattioli (1995) and

Erba (2004) interpreted Calyculus as a deep to intermediate-dwelling taxon, considering the expanded and shallower nutricline at the beginning of the Toarcian. However, Mattioli et al. (2008) argued that if the photic zone was low saline and intermittently anoxic, Calyculus could not be a deep or intermediate-dweller, as previously proposed.

The species belonging to the genus Biscutum have been inter- preted as shallow-dwelling taxa (e.g. Erba, 2004; Tremolada et al., 2005), since they sharply increase in abundance during black shale deposition, indicating a slight rise of the nutricline caused by the input of nutrients from the continent. Several authors have consid- ered the species $B$. finchii and $B$. novum as meso-eutrophic taxa and as high fertility indices (e.g. Bucefalo Palliani and Mattioli, 1995; Bucefalo Palliani et al., 2002; Mattioli and Pittet, 2004; Mattioli et al., 2008). Aguado et al. (2008) suggested that the species Biscutum dubium, Biscutum intermedium and Biscutum depravatum were

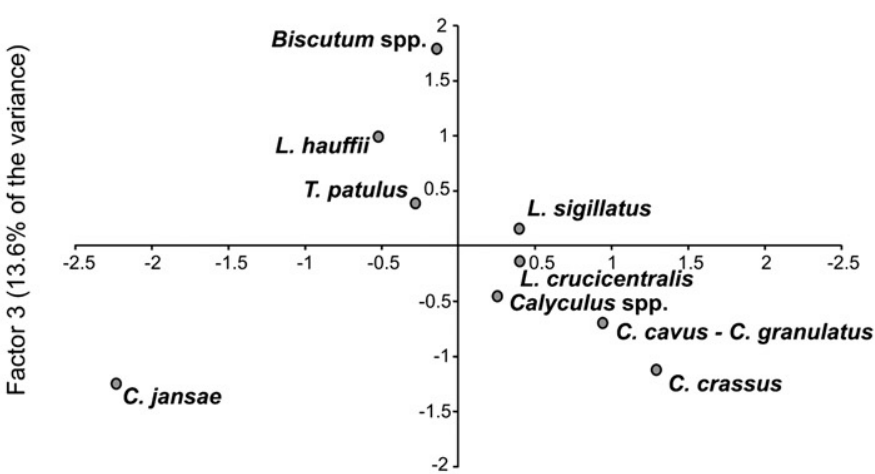

Factor $1(40.6 \%$ of the variance) 


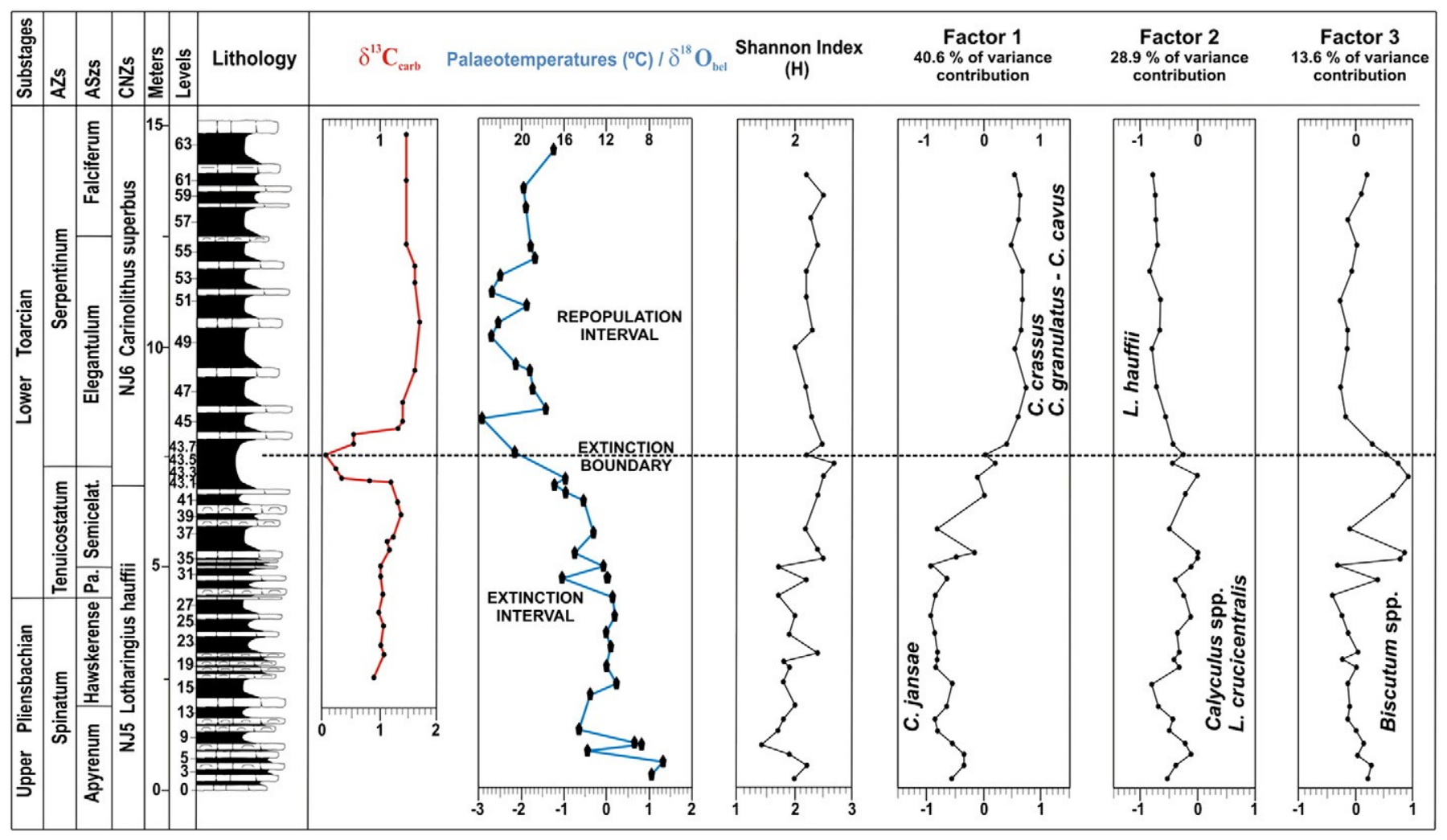

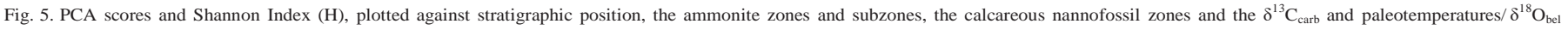
curves of the West Rodiles section. The contribution to the variance of each factor and the most significant species contributing to the factors, are shown.

eutrophic taxa, because they observed high proportions of these taxa coinciding with a very significant decrease in the abundances of Schizosphaerella spp. and C. crassus together with the highest values in $\delta^{13} \mathrm{C}_{\text {carb. }}$. Tremolada et al. (2006a) observed high proportions of the species of Biscutum coinciding with a significant positive excur- sion in $\delta^{18} \mathrm{O}$, suggesting that these taxa were probably adapted to cooler surface waters.

According to the literature (e.g. Mattioli and Pittet, 2004; Tremolada et al., 2005) the genus Lotharingius has paleoecological af- finities similar to those of Biscutum, and has also been interpreted as meso-eutrophic. Moreover, Mattioli et al. (2008) suggested that Lotharingius species probably dwelled in shallow waters, and that the dominance of these taxa after the anoxia may mean renewed input of nutrients to surface waters.

\subsection{The influence of temperature on nannoplankton assemblages}

In this work, paleotemperatures are calculated on the basis of the $\delta^{18} \mathrm{O}$ values measured on diagenetically screened belemnite calcite. Re- cently, Rexfort and Mutterlose (2009) compared the $\delta^{18} \mathrm{O}$ and $\delta^{13} \mathrm{C}$ sig- nals of ten recent cuttlebones (internal shells) from sepias for estimating the effects of temperature variations and salinity changes on these organisms. All analyzed specimens perfectly reflected the tem- perature characteristics of their habitat, and sudden short-term salinity changes were not observed. The cuttlebones are considered analogous with belemnites; therefore, $\delta^{18} \mathrm{O}$ values measured on belemnite calcite could be considered a powerful tool for inferring paleotemperatures.

In the West Rodiles section, average calculated paleotemperatures for the uppermost Pliensbachian Spinatum AZ are in the order of

$11.6^{\circ} \mathrm{C}$ (Figs. 2 and 5). This temperature can be considered as notably low, for a calculated paleolatitude of $30^{\circ} \mathrm{N}$ during the Toarcian based on paleomagnetical studies (Osete et al., 2000, 2011). A first step of progressive seawater warming started in the Lower Toarcian Ten- uicostatum AZ, reaching an average paleotemperature of $15.4^{\circ} \mathrm{C}$ in the West Rodiles area. A sudden increase in seawater temperature was recorded around the Tenuicostatum/Serpentinum AZ and extinc- tion boundary, reaching average values of about $21^{\circ} \mathrm{C}$. This significant

and rapid warming, which represents an $\Delta \mathrm{T}$ of about $6{ }^{\circ} \mathrm{C}$ with re- spect to the Tenuicostatum AZ, continues through the Serpentinum

AZ and the Middle Toarcian Bifrons AZ, above the studied part of the section (Gómez et al., 2008). Consequently, the highest tempera- tures were reached in the repopulation interval, above the extinction boundary, coinciding with the major changes in nannofossil assem- blages. Apparently, critical paleoenvironmental changes which pro- duced the calcareous nannofossil crisis were reached before maximum paleotemperatures were recorded, maybe because a temperature threshold was surpassed. It is possible that above this critical tempera- ture only some species well adapted could survive.

Results presented in this study and in numerous studies world- wide have documented that a great amount of organisms constitut- ing the plankton are very sensitive to temperature changes. Seawater temperature controls the latitudinal distribution of nanno- plankton (e.g. Hiramatsu and De Deckker, 1997), their abundance (e.g. Okada and Wells, 1997; Findlay and Giraudeau, 2000; Dimitrenko, 2004), and the variations recorded in the plankton as- semblages (e.g. Hiramatsu and De Deckker, 1997; Legge et al., 2008; Sheldon et al., 2010). Consequently, the changes in assemblage composition and the abundance of some taxa have been used in many studies to interpret climatic changes (e.g. Haq et al., 1977; Tremolada et al., 2006b; Sinaci and Toker, 2009). In addition, numer- ous papers have established a close correlation between warming in- tervals and the crises recorded in calcareous nannoplankton assemblages. Some of the best examples have been observed in sec- tions containing the Paleocene-Eocene thermal maximum (PETM), in which important extinctions or drops in nannoplankton produc- tivity, coincident with one of the most important events of rapid warming, have been reported (e.g. Bralower, 2002; Gibbs et al., 2004, 2006; Agnini et al., 2007; Bown and Pearson, 2009). These 
examples can be considered as comparable to the Early Toarcian warming, during which some taxa disappeared and, moreover, drops in productivity were recorded in many areas (e.g. Bucefalo Palliani et al., 1998, 2002; Mattioli et al., 2004a,b; Suan et al., 2008; this study).

Nevertheless some organisms, like Calyculus spp. and L. sigillatus in the studied section, show an acme coinciding with the pronounced environmental changes. In other warming intervals, like in the case of the PETM, dinoflagellate cyst acmes coincident with the onset of this thermal event have been documented (Crouch et al., 2001; Gibbs et al., 2004). These peaks in relative abundances, and in this study also in the second PCA factor (Figs. 3 and 5) which receives important contribution of Calyculus spp. and $L$. sigillatus around the extinction boundary, have been interpreted as a response of these stress tolerant taxa to important environmental changes (Gibbs et al., 2004).

Climate change is being considered as one of the main factors causing biotic crises. Twitchett (2006) analyzed the possible causes of the big five mass extinction events, concluding that all these events are associated with evidence of climatic change and that environmen- tal consequences of rapid global warming have been particularly det- rimental to the biosphere. In addition, the responses of the organisms to current warming in the oceans represent a source of information on mechanisms by which climate change affects individual physiolo- gy, seasonal timing, phenology of organisms, composition and dy- namics of populations and geographic distribution (Walther et al., 2002). Each species has an optimum temperature range for skeletal secretion, biochemical and physiological activity and growth, but if physiological upper thermal limit is surpassed, thermal stress may become lethal (Twitchett, 2006).

Severe warming also causes a more sluggish oceanic circulation and reduced upwelling, which lead to a global decrease in nutrients trans- port to the planktonic organisms living in the upper layer of the oceans, affecting the primary and secondary production (Walther et al., 2002; Kidder and Worsley, 2004; Twitchett, 2006). Other important ways by which temperature increases may lead to mass extinctions are the phenologic processes, the losses and fragmentations of habitats, and the loss of species with low adaptability and/or low dispersal capacity (Gómez and Goy, 2011).

It seems clear that warming can be a direct or indirect responsible of mass extinctions, and can induce severe decreases in the availability of nutrients for phytoplankton growth. Warming events can destroy the trophic net, reduce the ocean productivity and lead to mass mortality, which can be envisaged as one of the probable causes of the Early Toarcianmassextinction.

\subsection{Hypotheses proposed in the literature to interpret the Early Toarcian nannofossil crisis}

The causes of Early Toarcian crisis affecting the nannofossils should be interpreted in conjunction with the strong crisis recorded in other nektonic and benthic organisms, which led to the remarkable mass ex- tinction that occurred during this time interval. An excellent correlation between the Early Toarcian warming and the decrease of biodiversity in different organisms, has been shown for ostracods (Gómez and Arias, 2010), brachiopods (García Joral et al., 2011), nannofossils (Fraguas, 2010) and other nektonic, planktonic and benthic organisms (Gómez and Goy, 2010, 2011). Suan et al. (2010) concluded that the amount of nannofossils and the size of Schizosphaerella largely covary with paleotemperature during the Late Pliensbachian-Early Toarcian time in- terval in the LusitanianBasin(Portugal).

Nevertheless, other hypotheses to explain the Early Toarcian nannofossils crisis, in general independently from the mass extinction recorded in other groups of organisms, have been previously proposed. Bucefalo Palliani et al. (2002) explained the temporary decrease in pe- lagic carbonate production and the temporal disappearance of calcare- ous nannofossils and dinoflagellate cysts (disappearance event)
(Fig. 6.1) as due to a stronger water column stratification and the devel- opment of an oxygen-minimum zone. However, there is no clear coin- cidence between anoxia and the disappearance of nannofossils and dinoflagellate cysts, since the disappearance is recorded before the onset of deposition of black shales; which has been used as an indicator of anoxic conditions (Jenkyns, 1988). Bucefalo Palliani et al. (2002) ob- served the reappearance of nannofossils and dinoflagellate cysts at a level with relatively high values of TOC, just after the maximum values. In the Causses area of central France there is a significant hiatus at the Pliensbachian/Toarcian boundary and the deposits of the Tenuicostatum $\mathrm{AZ}$ are almost entirely absent, so no record of the extinction interval is present. However, it is also striking in this area that the highest nannofossil abundance coincides with some of the highest TOC values (Mailliot et al., 2009). If the TOC values are taken as an index of anoxia, high TOC values should not co-occur with the highest nannofossils abundance, suggesting that the biotic crisis cannot be due to anoxia.

Another hypothesis defended by Mattioli et al. (2004b, 2009), Tremolada et al. (2005) and Suan et al. (2008) is based on the as- sumption that atmospheric $p \mathrm{CO}_{2}$ had high values at this time, and that it was responsible for the nannofossil crisis. The postulated in- crease in atmospheric $p \mathrm{CO}_{2}$ and, consequently, the biocalcification crisis would be caused by the magmatic activity of the Karoo and Fer- rar LIP and by the release of methane (Mattioli et al., 2004b). On one hand, attempts to calculate the Early Toarcian $p \mathrm{CO}_{2}$ concentrations failed, since unreasonably high values of 35 times the modern pre- industrial level of $280 \mathrm{ppm}$ were obtained by Sælen et al. (1998) and, consequently, results were discarded. On the other hand, causes of this postulated Early Toarcian increase in $p \mathrm{CO}_{2}$ are also uncertain. The magmatic activity and the release of methane explaining the high atmospheric $p \mathrm{CO}_{2}$ enounced by Mattioli et al. (2004b), would imply the presence of a negative excursion in the $\delta^{13} \mathrm{C}$ values, as in both cases isotopically light carbon would be released to the earthatmosphere system. There is a negative $\delta^{13} \mathrm{C}$ excursion recorded in bulk carbonates and organic matter in many sections worldwide, but to establish a cause-and-effect relationship, this negative $\delta^{13} \mathrm{C}$ excursion must be synchronous, coincident in time with the bio- calcification crisis. However, the negative $\delta^{13} \mathrm{C}$ excursion seems to be diachronous with respect to the ammonite zones and subzones. In the section studied here, as well as in other Spanish and European sections, the negative $\delta^{13} \mathrm{C}$ excursion coincides with the extinction boundary. Conversely, in some other sections the negative $\delta^{13} \mathrm{C}$ excursion coincides with the repopulation interval.

In addition, the hypothesis that the negative $\delta^{13} \mathrm{C}$ excursion could be attributed to outgassing of isotopically light $\mathrm{CO}_{2}$ as a product of the vol- canic activity of the Karoo and Ferrar LIP, proposed by Mattioli et al. (2004b) and Suan et al. (2008), has been questioned by Littler et al. (2010) because taking an average $\delta^{13} \mathrm{C}$ value for the mantle of $-6 \%$, the volumes of volcanogenic $\mathrm{CO}_{2}$ needed to generate the large negative $\delta^{13} \mathrm{C}$ excursion recorded in many sections of Europe would be unrealis- ticallyhuge.

The massive release of large amounts of isotopically light $\mathrm{CH}_{4}$ from the thermal dissociation of gas hydrates (Hesselbo et al., 2000, 2007; Cohen et al., 2004; Kemp et al., 2005), the other possibility to produce high $p \mathrm{CO}_{2}$, would imply that the negative $\delta^{13} \mathrm{C}$ excursion found in many Early Toarcian sections should be synchronous and global in ex- tent. Nevertheless, the global extent has been questioned by the lack of signal in belemnites (van de Schootbrugge et al., 2005; Wignall et al., 2005; McArthur, 2007; Gómez et al., 2008) and, as mentioned above, the correlation of the available worldwide sections suggests that this negative $\delta^{13} \mathrm{C}$ excursion is diachronous with respect to the ammonite biostratigraphy. Consequently, as was previously pointed out by Suan et al. (2008), in many parts of Europe, it does not coincide with the biocalcification crisis.

Another hypothesis proposed by Mattioli et al. (2009) to explain the biocalcification crisis, deals with the discharge of low saline arctic 


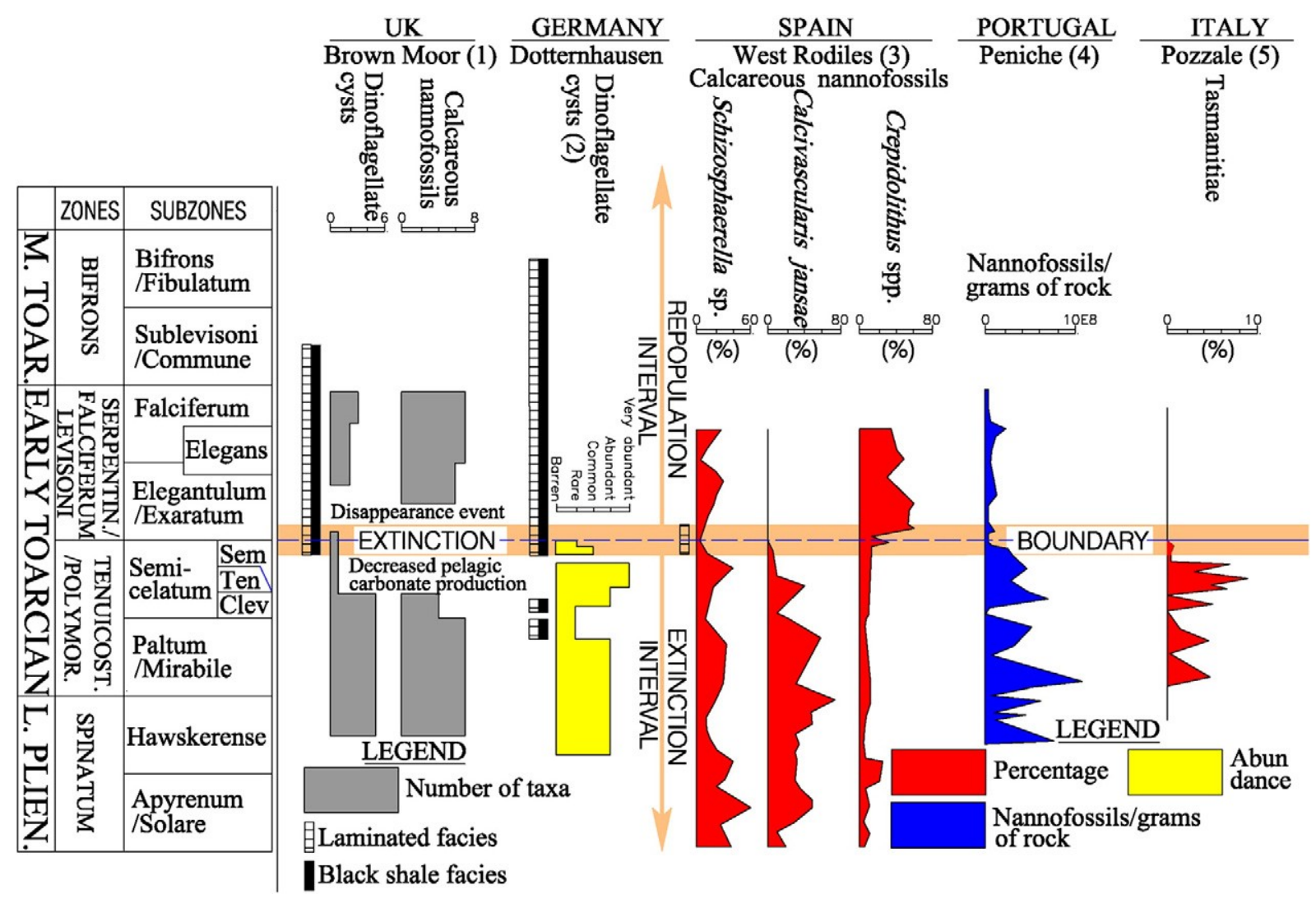

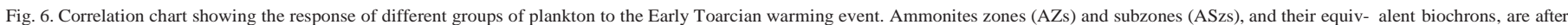

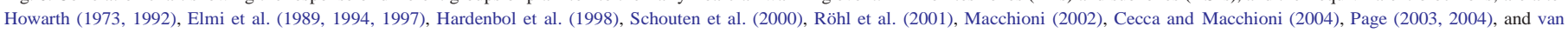

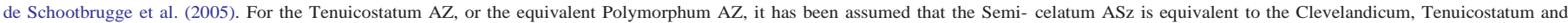

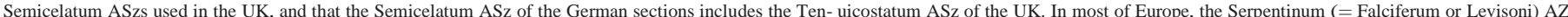

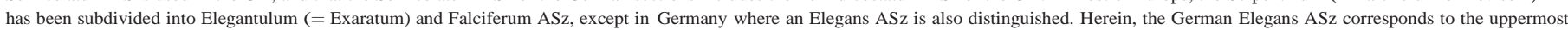

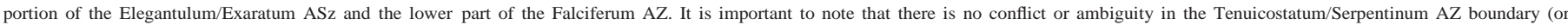

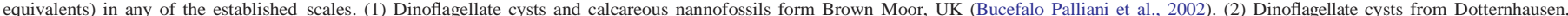

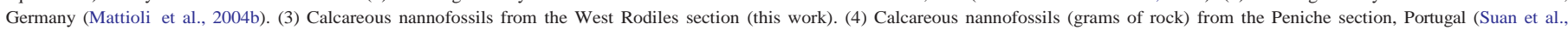
2008; Mattioli et al., 2009). (5) Tasmanites from the Pozzale section, Italy (Bucefalo Palliani et al., 1998).

waters through the Laurasian seaway, which generated hostile condi- tions for nannoplankton production. According to many authors (Prauss et al., 1991; Sælen et al., 1998; Bjerrum et al., 2001), salinity in the southern part of the Laurasian seaway, corresponding to Western Europe, was most likely close to normal, whereas farther north, towards the Arctic region, salinity might have been reduced by up to $10 \mathrm{psu}$. In fact, quantitative modelling of seawater salinity during the deposition of the Early Toarcian Whitby Mudstone Formation of the Yorkshire area of the UK (Sælen et al., 1996), indicates a maximum salinity lower- ing of $\sim 5 \%$ compared to the average salinity of contemporaneous normal seawater (35\%), which cannot be considered as significant enough to generate hostile conditions for plankton production, given the wide range of tolerance of modern coccoliths (Kilham and Kilham, 1980). For instance, Emiliania huxleyi can tolerate a salinity range of $16 \%$ o to 54\% (Haq, 1978). The connection between the Arctic region and the Western Tethys through the Laurasian seaway was established since the Late Triassic-earliest Jurassic (Ziegler, 1990; Stampfli and Borel, 2002, 2004). If hostile conditions for nannoplankton production were generated by the lowering of salinity due to the southward dom- inant paleocurrents circulating in this connection, the biocalcification crisis should have started at the Late Triassic-earliest Jurassic and have continued for millions of years. But the crisis occurred at a specific and relatively short time interval. No significant changes in the ostracod assemblages (organisms highly sensitive to salinity) of this age have been reported in Spain (i.e. Arias, 1997, 2006; Gómez and Arias, 2010) and Western Europe (Arias, 2007), and no substantial changes in salin- ity are supported by the oxygen isotopes obtained from belemnite or brachiopod calcite. Their values reflect reasonably normal seawater paleotemperatures, without any indication of being influenced by low marine salinity values.

Consequently, based on the available data, the good correlation between the marked temperature change and the biotic crisis and the lack of other satisfactory explanations, we hypothesize that warming and the environmental changes derived from temperature changes can be considered as the main responsible for the mass ex- tinction event. Nevertheless, possible changes in other environmental parameters related or not to warming, are not discarded.

\subsection{Nannofossil assemblages and climate change before the extinction boundary}

Oxygen isotope values measured on belemnite calcite in the West Rodiles section suggest the presence of a marked cooling interval dur- ing the Spinatum AZ. These data are consistent with data from other parts of the world, indicating that this cooling event is probably of global extent (e.g. Bailey et al., 2003; Rosales et al., 2004; van de Schootbrugge et al., 2005; Gómez et al., 2008; Suan et al., 2008, 2010; Gómez and Arias, 2010; Gómez and Goy, 2010, 2011; García Joral et al., 2011). For some authors, the Late Pliensbachian represents one of the main candidates in the Mesozoic for the formation of polar 
ice (Price, 1999), up to the point that the Upper Pliensbachian-lower- most Toarcian hiatus, recorded in some of the European and Northern African sections, has been interpreted by Guex et al. (2001) as due to a major shortlived regression, forced by cooling and glaciation.

Quantitative analysis reveals the coincidence of especially high relative abundances of Schizosphaerella sp. and C. jansae coinciding with the uppermost Pliensbachian cold period. Even if these taxa are more abundant in the southern margin of Tethys (Bown, 1987; Bown and Cooper, 1998; Bucefalo Palliani et al., 2002; Mattioli et al., 2008), the Tethyan waters were most probably also affected by the cooling event that globally lowered seawater temperature, meaning that these low latitude waters were not as warm as expected under normal climatic conditions. This hypothesis is supported by the calculation of Uppermost Pliensbachian paleotemperature in Europe, based on the compilation of the available $\delta^{18} \mathrm{O}_{\text {bel }}$ data (e.g. Sælen et al., 1996; Jenkyns, 2003; Rosales et al., 2004; Gómez et al., 2008; Metodiev and Koleva-Rekalova, 2008; Suan et al., 2008; Dera et al., 2009; Gómez and Arias, 2010; García Joral et al., 2011; Gómez and Goy, 2011). Calculated average seawa- ter paleotemperature in Europe for this interval was $13.7^{\circ} \mathrm{C}$ as indi- cated by this compilation (Gómez and Goy, 2011), lower than the expected paleotemperature from the paleolatitudinal position of Eu- rope at this time (Osete et al., 2011).

Reggiani et al. (2010) observed a major reorganization in the phyto- plankton community structure during the Late Pliensbachian of Portugal, where assemblages dominated by $C$. crassus during a warm period, the Margaritatus AZ, became dominated by Mitrolithus jansae and Schizosphaerella spp. during the Late Pliensbachian Spinatum AZ cooling period. These authors explain the dominance of taxa with a Mediterranean affinity (Bown, 1987; Bown and Cooper, 1998; Bucefalo Palliani et al., 2002; Mattioli et al., 2008) in a period of progres- sive cooling of surface waters by reduced connections between the water masses of the Lusitanian Basin and those of the NW European epi- continental seas. However, in the West Rodiles section there are no data supporting this hypothesis.

Through the Tenuicostatum AZ, an increase in seawater tempera- ture, estimated in the order of $4{ }^{\circ} \mathrm{C}$ (Figs. 2 and 5), was recorded in the West Rodiles section, resulting in temperatures averaging $15.4{ }^{\circ} \mathrm{C}$. This first warming interval occurs in two steps, in the Paltum ASz temperature increases by 2.2 ${ }^{\circ} \mathrm{C}$, reaching average values of $13.8{ }^{\circ} \mathrm{C}$ and next, in the Semicelatum ASz there is a further temperature in- crease of about $2.1{ }^{\circ} \mathrm{C}$, and average temperatures of $15.9^{\circ} \mathrm{C}$ were reached.

In the West Rodiles section, the third PCA factor has an important positive contribution of the Biscutum taxa (Fig. 5). The high relative abundance of this genus during a period of warming indicates the preference of Biscutum spp. for warm surface waters and not for cold seawaters as Tremolada et al. (2006a) previously proposed.

The relative abundance curves of Schizosphaerella sp. and $C$. jansae show a clear similarity with the $\delta^{18} \mathrm{O}_{\text {bel }}$ /paleotemperature curve, with a decline in the relative abundance of these taxa as temperature rises (Fig. 3). Based on this observation, a clear relationship between the decreasing relative abundances of these taxa and the increase in seawater paleotemperatures may be hypothesized. This interpreta- tion is consistent with the hypothesis of Suan et al. (2010), who suggested that the calcium carbonate $\left(\mathrm{CaCO}_{3}\right)$ contents, the amount of nannofossil calcite and the mean size of the major pelagic carbon- ate producer Schizosphaerella covary with paleotemperatures, indi- cating a coupling between climatic conditions and both pelagic and neritic $\mathrm{CaCO}_{3}$ production.

Neither the schizosphaerellid decline around the Pliensbachian/

Toarcian boundary nor the increase in the relative abundance of $C$. jansae coinciding with a decrease in the percentages of Schizosphaerella sp., reported in the Castillo Pedroso section (Basque-Cantabrian Basin) by Tremolada et al. (2005), have been recognized in the West Rodiles sec- tion (Fig. $6.3)$.
Coinciding with the first step of warming, during the Tenuicostatum Chronozone, planktonic organisms were affected in many areas of Eu- rope. Bucefalo Palliani et al. (2002) noticed the presence of two inter- vals marked by a prominent decrease in the number of species of calcareous nannofossils and dinoflagellate cysts in the Brown Moor Borehole, North Yorkshire, UK. The lower interval, located immediately below the extinction boundary, is marked by the decrease of pelagic carbonate production and can be correlated with the progressive in- crease in paleotemperature recorded in the Yorkshire area (McArthur et al., 2000). The second interval, located immediately above the extinc- tion boundary, is marked by the disappearance of calcareous nannofossils and dinoflagellate cysts (Fig. 6.1) which coincides with the rapid increase in seawater temperature observed by McArthur et al. (2000). Bucefalo Palliani et al. (2002) observed that the same taxa of calcareous nannofossils reappear when TOC values decrease, aftermaximum values.

With respect to other phytoplankton groups, which are often studied together with calcareous nannofossils, a marked crisis in the dinoflagellate cysts, which temporarily also disappeared, has been reported in the extinction interval in the Dotternhausen section, Ger- many (Mattioli et al., 2004b), predating the base of the succession enriched in organic matter (Fig. 6.2). Bucefalo Palliani et al. (1998) observed a dramatic decrease in the relative abundance of Tasmanites (cysts of Prasinophyte algae) in the Pozzale section, Italy, which be- came extinct just after the extinction boundary (Fig. 6.5).

In the Peniche section of Portugal, Suan et al. (2008) and Mattioli et al. (2009) reported a dramatic decrease in the absolute abundance of nannofossils (Fig. 6.4), and a less pronounced decrease in the size of Schizosphaerella. No organic-rich deposits were found in these Por- tuguese section (Hesselbo et al., 2007), but the Early Toarcian warming was also measured in this area in brachiopod calcite (Suan et al., 2008, 2010). These data are comparable with the results obtained in this study, marked by the progressive decrease in the rel- ative abundance of Schizosphaerella sp. and C. jansae (Fig. 6.3).

\subsection{Nannofossil assemblages and rapid warming at the extinction boundary}

In the West Rodiles section, the Tenuicostatum/Serpentinum AZs boundary was characterized by a substantial rise in seawater temper- ature and a transgressive peak (Gómez and Goy, 2005, 2011; Gómez et al., 2008; García Joral et al., 2011). Around the extinction boundary, the average seawater temperature was estimated at $21^{\circ} \mathrm{C}$, rep- resenting an increase of about 6 ${ }^{\circ} \mathrm{C}$ with respect to the extinction in- terval (Figs. 2 and 5).

Schizosphaerella sp. shows its minimal relative and absolute abun- dance values around the Tenuicostatum/Serpentinum AZs and extinc- tion boundary (Figs. 2 and 3). In other European sections, a sharp decrease in both size and abundance of calcareous nannofossils was recorded during the Early Toarcian (e.g. Bucefalo Palliani et al., 2002; Erba, 2004; Mattioli et al., 2004a, 2004b; Tremolada et al., 2005; Mattioli et al., 2008; Suan et al., 2008) that we interpreted as due to the recorded climatic change. For example, Schizosphaerella sp. undergoes a drastic decrease in both abundance and size during the Early Toarcian, which has been termed the schizosphaerellid cri- sis, biocalcification crisis or disappearance event (Bucefalo Palliani et al., 1998, 2002; Mattioli and Pittet, 2002; Erba, 2004; Mattioli and Pittet, 2004; Mattioli et al., 2004b; Tremolada et al., 2005; van de Schootbrugge et al., 2005; Mattioli et al., 2008; Suan et al., 2008; Mattioli et al., 2009). Mattioli et al. (2004a) hypothesized an influence of critical conditions during the postulated Early Toarcian anoxic event on coccolith size. Recently, Fraguas and Young (2011) in a bio- metric analysis performed on three species of the genus Lotharingius, observed a significant decrease in the size of two of the species or "dwarfism" and the disappearance of the largest one, L. crucicentralis, coinciding with the Early Toarcian climate shift. After the event, the 
largest species re-appeared with a big size and the other two taxa re- covered the pre-event sizes.

Significant peaks in the relative abundances of the coccolith taxa Calyculus spp. and L. sigillatus (Fig. 3 ) and in the second PCA factor, which is strongly loaded by Calyculus spp. (Fig. 5) were recorded around the extinction boundary in the West Rodiles section. Calyculus spp. have been considered as adapted to live near the surface of a stratified water column (Mattioli et al., 2008). The especially high relative abundance of this genus during the extinction interval could indicate the presence of low productivity conditions and a strong seawater stratification.

\subsection{Nannofossil assemblages after the extinction boundary}

During the repopulation interval, a substantial increase in the relative abundances of the species belonging to the coccolith genera Crepidolithus and Lotharingius, is well marked in the West Rodiles sec- tion (Fig. 3). Moreover, a peak in the first PCA factor, with strong load- ings for the species of Crepidolithus, and relative high Shannon diversity Index values have been recorded in samples above the extinc- tion boundary (Fig. 5). Based on the especially high relative abundances of $C$. crassus and Lotharingius taxa, which in the majority of the cases represents more than $50 \%$ of the total coccoliths, we infer a return to high nutrients concentrations during the repopulation interval. This is consistent with the progressive higher $\delta^{13} \mathrm{C}_{\text {bel }}$ values observed after the extinction boundary in the West Rodiles section. Considering this information, Crepidolithus spp. and Lotharingius spp. could be inter- preted as opportunistic taxa that probably occupied a part of the ecolog- ical niche previously occupied by Schizosphaerella sp. and C. jansae. Mattioli et al. (2008) found similar results in different sections from NW Europe, and they interpreted the successive pulses of Lotharingius spp. (shallow dweller) and C. crassus (deep dweller) in terms of pro- gressive restoration of environmental conditions at different depths within the photic zone.

The relative abundances of the taxa Calyculus spp. and Biscutum spp. sharply decrease after the extinction boundary, and the species $C$. jansae becomes extinct just above this boundary, possibly because it could not survive to the significant Early Toarcian seawater warming.

\section{Conclusions}

Quantitative nannofossil data have been compared to geochemical information ( $\left(\delta^{13} \mathrm{C}_{\text {carb }}\right.$, $\delta^{13} \mathrm{C}_{\text {bel }}$ and $\delta^{18} \mathrm{O}_{\text {bel }}$ curves and the wt.\% TOC values) in order to interpret the paleoenvironmental changes recorded during the Late Pliensbachian-Early Toarcian time interval in Asturias (Northern Spain).

During the latest Pliensbachian-earliest Toarcian time interval, before the extinction boundary, Schizosphaerella sp., T. patulus and C. jansae, taxa with a putative affinity for rather cold waters, dominated the nannofossil assemblages. The relative abundances of Schizosphaerella sp., C. jansae and

T. patulus and the absolute abundance of Schizosphaerella sp., show a high similarity with the estimated paleotemperature curve. We hypothesize a clear relationship between the increase in paleotemperature and the changes recorded in nannofossil assemblages.

The dominance of Biscutum spp. slightly below the extinction boundary may be interpreted as a preference of these taxa for warm seawaters. The especially high relative abundance of Calyculus spp. during the extinction interval could indicate the presence of low car- bonate production conditions, coinciding with the deposition of the laminated shales. The peaks in relative abundances of Calyculus spp. and L. sigillatus around the extinction boundary have been inter- preted as a response to high-stress paleoenvironmental conditions.

After the extinction boundary, a return to high nutrients concen- trations has been inferred, based on the progressive higher $\delta^{13} \mathrm{C}_{\text {bel }}$ values. Moreover, high relative abundances, $>50 \%$ of the total coccoliths, of the genera Crepidolithus and Lotharingius have been recorded during the repopulation interval. Therefore,Crepidolithus spp. and Lotharingius spp. could be interpreted as opportunistic taxa that probably occupied a part of the ecological niche previously occupied by Schizosphaerella sp. and C. jansae.

Based on the covariance between the observed nannofossil crisis and the evolution of seawater paleotemperature, and taking into ac- count that none of the other proposed explanations seems to satisfy, warming can be considered as one of the main causes conducting di- rectly or indirectly to the Early Toarcian mass extinction.

\section{Acknowledgments}

We are grateful to Dr. Emanuela Mattioli for the sample prepara- tion and the critical reading of this manuscript. We want to thank the valuable help and comments of Dr. Paul Bown on the earliest ver- sion of this work. This manuscript benefited from the critical com- ments and valuable suggestions by two anonymous reviewers and the editor (Dr. Frans Jorissen). It was supported by the research pro- jects GR58/08B/910431, GR58/08A/910429 and GR58/08A/91039 of

the Universidad Complutense de Madrid (BSCH-UCM) and CGL 200803112/BTE of the Spanish Ministerio de Ciencia y Tecnología, and a UCM research fellowship.

\section{AppendixA}

Alphabetical listing of all the taxa mentioned in the text with full author citations:

B. depravatum (Grün and Zweili, 1980) Bown, 1987

B. dubium (Noël, 1965) Grün in Grün et al., 1974

B. finchii Crux, 1984 emend. Bown, 1987 (=Similiscutum novum sensu de Kaenel and Bergen, 1993)

B. grande Bown, 1987

B. intermedium Bown, 1987

B. novum (Goy in Goy et al., 1979) Bown, 1987 (=Similiscutum novum sensu Mattioli et al., 2004a)

C. jansae Wiegand, $1984 ;^{(*)}$

Calyculus spp. 1974

C. superbus (Deflandre in Deflandre and Fert, 1954) Prins in Grün et al.,

C. crassus (Deflandre in Deflandre and Fert, 1954) Noël, 1965

C. cavus Prins, 1969, ex Rood et al., 1973

C. granulatus Bown, 1987

E. huxleyi (Lohmann, 1902) Hay and Mohler, 1967

F. profunda Okada and Honjo (1973)

L. crucicentralis (Medd, 1971) Grün and Zweili, 1980

L. hauffii Grün and Zweili, 1974 in Grün et al., 1974, emend. Goy, 1979 in Goy et al., 1979

L. sigillatus (Stradner, 1961) Prins in Grün et al., 1974

Schizosphaerella sp.

T. patulus Prins, 1969, ex Rood et al., 1973

(*) The genus affiliation Calcivascularis has been used instead of Mitrolithus jansae, since $C$. jansae differs in rim feature and central area structure from the other species of the genus Mitrolithus, such as $M$. elegans and $M$. lenticularis, coccoliths with an outer rim of thin and broad calcite laths with a central spine that is initially nar- row before broadening out (Deflandre in Deflandre and Fert, 1954; Bown, 1987). By contrast, C. jansae is a basket shaped species (i.e. a high-walled murolith) filled with a core of radially arranged ele- ments (Wiegand, 1984).

\section{References}

Aberhan, M., Baumiller, T.K., 2003. Selective extinction among Early Jurassic bivalves: a consequence of anoxia. Geology 31, 1077-1080.

Agnini, C., Fornaciari, E., Rio, D., Tateo, F., Backman, J., Giusberti, L., 2007. Responses of calcareous nannofossil assemblages, mineralogy and geochemistry to the envi- ronmental perturbations across the Paleocene/Eocene boundary in the Venetien Pre-Alps. Marine Micropaleontology 63, 19-38. 
Aguado, R., O'Dogherty, L., Sandoval, J., 2008. Fertility changes in surface waters during the Aalenian (mid-Jurassic) of the Western Tethys as revealed by calcareous nannofossils and carbon-cycle perturbations. Marine Micropaleontology 68, 268-285.

Alméras, Y., Elmi, S., 1993. Palaeogeography, physiography, paleoenvironments and brachiopod communities. Examples of the Liassic brachiopods in the Western Te- thys. Palaeogeography, Palaeoclimatology, Palaeoecology 100, 95-108.

Anderson, T.F., Arthur, M.A., 1983. Stable isotopes of oxygen and carbon and their appli- cation to sedimentologic and paleoenvironmental problems. In: Arthur, M.A. (Ed.), Stable Isotopes in Sedimentary Geology: SEPM Short Course, 10. pp. 1-1-1-151.

Arias, C., 1997. Ostracod biostratigraphy of the Lower Toarcian in the Cordillera Ibérica, North-East Spain. Neues Jahrbuch für Geologie und Paläontologie, Abhandlungen 206, 67-91.

Arias, C., 2006. Northern and Southern Hemisphere ostracod palaeobiogeography during the Early Jurassic: possible migration routes. Palaeogeography, Palaeoclimatology, Palaeoecology 233, 63-95.

Arias, C., 2007. Pliensbachian-Toarcian ostracod biogeography in NW Europe: evidence for wate mass structure evolution. Palaeogeography, Palaeoclimatology, Palaeo- ecology 251, 398421.

Arias, C., 2009. Extinction pattern of marine Ostracoda across the Pliensbachian- Toarcian boundary in the Cordillera Ibérica, NE Spain: causes and consequences. Geobios 42, 1-15.

Arias, C., Comas-Rengifo, M.J., Goy, A., Herrero, C., Ruget, C., 1992. Variations dans les associations de brachiopodes, foraminifers et ostracodes du Toarcien basal dans un secteur central de la Cordillère Ibérique. Un example dans la "Rambla del Salto" (Teruel, Espagne). Cahiers de l'Université Catholique de Lyon 5, 5-25.

Bailey, T.R., Rosenthal, Y., McArthur, J.M., van de Schootbrugge, B., Thirlwall, M.F., 2003. Paleoceanographic changes of the Late Pliensbachian-Early Toarcian interval: a possible link to the genesis of an Oceanic Anoxic Event. Earth and Planetary Sci- ence Letters 212, $307-320$.

Bassoullet, J.P., Baudin, F., 1994. Le Toarcien inférieur: une période de crise dans les bassins et sur les plate-formes carbonatées de l'Europe du Nord-Ouest et de la Té- thys. Geobios 17 , 645-654.

Bassoullet, J.P., Lachkar, G., Baudin, F., Benshili, K., Blanc, P., Boutakiout, M., Depêche, F., Elmi, S., Ruget, C., 1991. Stratigraphie intégrée dans le Toarcien du Maroc (rides sud- rifaines et Moyen Atlas). Bulletin de la Société Géologique de France 162, 825-839.

Bates, R.L., Jackson, J.A., 1987. Glossary of Geology. American Geological Institute, Alex- andria, Virginia, USA.

Beerling, D.J., Brentnall, S.J., 2007. Numerical evaluation of mechanisms driving Early Jurassic changes in global carbon cycling. Geology 35, 247-250.

Beerling, D.J., Lomas, M.R., Gröcke, D.R., 2002. On the nature of methane gas-hydrate dissociation during the Toarcian and Aptian oceanic anoxic events. American Jour- nal of Sciences 302, 28-49.

Bilotta, M., Venturi, F., Sassaroli, S., 2010. Ammonite faunas, OAE and the Pliensbachian- Toarcian boundary (Early Jurassic) in the Apennines. Lethaia 43, 357-380.

Bjerrum, C.J., Surlyk, F., Callomon, J.H., Slingerland, R.L., 2001. Numerical pale- oceanographic study of the Early Jurassic transcontinental Laurasian Seaway. Paleoceanography 16, 390404.

Boomer, I., Ainsworth, N.R., Exton, J., 1998. A re-examination of the Pliensbachian and Toarcian Ostracoda of Zambujal, west-central Portugal. Journal of Micropaleontology 17, 1-14.

Borrego, A.G., Hagemann, H.W., Blanco, C.G., Valenzuela, M., Suárez de Centi, C., 1996. The Pliensbachian (Early Jurassic) "anoxic" event in Asturias, northern Spain: Santa Mera Member, Rodiles Formation. Organic Geochemistry 25, 295-309.

Bour, I., Mattioli, E., Pittet, B., 2007. Nannofacies analysis as a tool to reconstruct paleoenvironmental changes during the Early Toarcian anoxic event. Palaeogeography, Palaeoclimatology, Palaeoecology 249, 58-79.

Bown, P.R., 1987. Taxonomy, evolution, and biostratigraphy of Late Triassic-Early Ju- rassic calcareous nannofossils. Special Papers in Palaeontology 38, 1-118.

Bown, P.R., Cooper, M.K.E., 1998. Jurassic. In: Bown, P.R. (Ed.), Calcareous Nannofossil Biostratigraphy. Kluwer Academic, London, pp. 34-86.

Bown, P.R., Pearson, P., 2009. Calcareous plankton evolution and the Paleocene/Eocene thermal maximum event: new evidence from Tanzania. Marine Micropaleontology 71, 60-70.

Bralower, T.J., 2002. Evidence of surface water oligotrophy during the Paleocene- Eocene thermal maximum: nannofossil assemblage data from Ocean Drilling Pro- gram Site 690, Maud Rise, Weddell Sea. Paleoceanography 17, http://dx.doi.org/ 10.1029/2001PA000662.

Bucefalo Palliani, R., Mattioli, E., 1995. Ecology of dinoflagellate cysts and calcareous nannofossils from bituminous facies of the Early Toarcian, Central Italy. Europal 8, 60-62.

Bucefalo Palliani, R., Cirilli, S., Mattioli, E., 1998. Phytoplankton response and geochem- ical evidence of the lower Toarcian sea level rise in the Umbria-Marche basin (Central Italy) Palaeogeography, Palaeoclimatology, Palaeoecology 142, 33-50.

Bucefalo Palliani, R., Mattioli, E., Riding, J.B., 2002. The response of marine phytoplank- ton and sedimentary organic matter to the Early Toarcian (Lower Jurassic) oceanic anoxic event in northern England. Marine micropaleontology 46, 223-245.

Caruthers, A.H., Gröcke, D.R., Smith, P.L., 2010. The Early Toarcian oceanic anoxic event in Western Canada. Earth Science Frontiers (Special issue) 17, 338-339.

Cecca, F., Macchioni, F., 2004. The two Early Toarcian (Early Jurassic) extinction events in ammonoids. Lethaia 37, 35-56.

Claps, M., Erba, E., Masetti, D., Melchiorri, F., 1995. Milankovitch-type cycles recorded in Toarcian black shales from the Belluno Trough (Southern Alps Italy). Memorie di Scienze Geologiche de Padova 47, 179-188.

Cobianchi, M., Picotti, V., 2001. Sedimentary and biological response to sealevel and palaeoceanographic changes of a Lower-Middle Jurassic Tethyan platform margin (South- ern Alps, Italy). Palaeogeography, Palaeoclimatololy, Palaeoecolology 169, 219-244.
Cohen, A.S., Coe, A.L., Harding, S.M., Schwark, L., 2004. Osmium isotope evidence for the regulation of atmospheric $\mathrm{CO}_{2}$ by continental weathering. Geology 32, 157-160.

Crouch, E.M., Heilman-Clausen, C., Brinkhuis, H., Morgan, H.E.G., Rogers, K.M., Egger, H., Schmitz, B., 2001. Global dinoflagellate event associated with the late Paleocene therma maximum. Geology 29, 315-318.

Crux, J.A., 1984. Biostratigraphy of Early Jurassic calcareous nannofossils from south- west Germany. Neues Jahrbuch für Geologie und Paläontologie, Abhandlungen 169, 160-186.

de Kaenel, E., Bergen, J.A., 1993. New Early and Middle Jurassic coccolith taxa and bio- stratigraphy from the eastern proto-Atlantic (Morocco, Portugal and DSDP Site 547 B). Eclogae Geologicae Helveticae 86, 861-908.

Deflandre, G., Fert, C., 1954. Observations sur les coccolithophorides actuels ets fossiles en microscopie ordinaire et electronique. Annales de Paléontologie 40, 115-176.

Dera, G., Pucéat, E., Pellenard, P., Neige, P., Delsate, D., Joachimski, M.M., Reisberg, L., Martínez, M., 2009. Water mass exchange and variations in seawater temperature in the NW Tethys during the Early Jurassic: evidence from neodymium and oxygen iso- topes of fish teeth and belemnites. Earth and Planetary Science Letters 286, 198-207.

Dera, G., Neige, P., Dommergues, J.-L., Fara, E., Laffont, R., Pellenard, P., 2010. High- resolution dynamics of Early Jurassic marine extinctions: the case of Pliensbachian- Toarcian ammonites (Cephalopoda). Journal of the Geological Society, London 167, 21-33.

Dimitrenko, O.V., 2004. Selected issues of the Cenozoic paleoecology of the nanno- plankton of the Southern Ocean. Oceanology 44, 856-866.

Elmi, S., Goy, A., Mouterde, R., Rivas, P., Rocha, R.B., 1989.Correlaciones bioestratigráficas en el Toarciense de la Península Ibérica. Cuadernos de Geología Ibérica 13, 265-277.

Elmi, S., Gabilly, J, Mouterde, R., Rulleau, L., Rocha, R.B., 1994. L'étage Toarcien de l'Europe et de la Téthys: divisions et corrélations. Geobios, Mémoire Spécial 17, 149-159.

Elmi, S., Dommerges, J.-L., Rulleau, L., Gabilly, J., Mouterde, R., 1997. In: Cariou, E., Hantzpergue, P. (Eds.), Toarcien-Groupe Français d'Étude du Jurassique- Biostratigraphie du Jurassique ouest-européen et méditerranéen: Zonations paral- lèles et distribution des invertébrés et microfossiles. : Bulletin des Centres de Recherches, vol. 17. Elf Exploration Production, pp. 120-125.

Erba, E., 2004. Calcareous nannofossils and Mesozoic oceanic anoxic events. Marine Micropaleontology 52, 85-106.

Findlay, C.S., Giraudeau, J., 2000. Extant calcareous nannoplankton in the Australian Sector of the Southern Ocean (austral summers 1994 and 1995). Marine Micropa- leontology 40, 417-439.

Fraguas, A., 2010. Late Sinemurian-Early Toarcian calcareous nannofossils from the Cantabrian Basin: spatial and temporal distribution. Ph.D. Thesis. University Com- plutense of Madrid. Madrid, Spain.

Fraguas, A., Young, J.R., 2011. Evolution of the coccolith genus Lotharingius during the Late Pliensbachian-Early Toarcian interval in Asturias (N Spain). Consequences of the Early Toarcian environmental perturbations. Geobios 44, 361-375.

García-Joral, F., Goy, A., 2009. Toarcian (Lower Jurassic) brachiopods in Asturias (Northern Spain): stratigraphic distribution, critical events and palaeobiogeography. Geobios 42, 255-264.

García Joral, F., Gómez, J.J., Goy, A., 2011. Mass extinction and recovery of the Early Toarcian (Early Jurassic) brachiopods linked to climate change in northern and central Spain.

Palaeogeography, Palaeoclimatololy, Palaeoecolology 302, 367-380. Geisen, M., Bollmann, J., Herrle,

J.O., Mutterlose, J., Young, J.R., 1999. Calibration of the random settling technique for calculation of nannoplankton. Micropaleontology 45, 437-442.

Gibbs, S., Bralower, T.J., Bohaty, S., Zachos, J., Sluijs, A., Brinkhuis, H., Quattlebaum, T., Bybell, L.M., 2004. Decoupled Shelf-Ocean Phytoplankton Productivity Responses across the Paleocene-Eocene Thermal Maximum: Geological Society of America 2004 Annual Meeting, Abstracts with Programs, 36, p. 303.

Gibbs, S.J., Bralower, T.J., Bown, P.R., Zachos, J.C., Bybell, L.M., 2006. Shelf and open-ocean calcareous phytoplankton assemblages across the Paleocene-Eocene thermal maxi- mum: implications for global productivity gradients. Geology 34, 233-236.

Gómez, J.J., 2002a. Sedimentologie du Mésozoïque de la Carte géologique de Berkane (NI-30XVI-4d), au 1:50.000. Editions du Service Géologique du Maroc. 16-36.

Gómez, J.J. 2002b. Sedimentologie du Mésozoïque de la Carte géologique de Zaïo (NI-30XVI-3d), au 1:50.000. Editions du Service Géologique du Maroc. 11-32. Gómez, J.J., Arias, C., 2010. Rapid warming and ostracods mass extinction at the Lower Toarcian (Jurassic) of central Spain. Marine Micropaleontology 74, 119-135.

Gómez, J.J., Goy, A., 2000. Definition and organization of limestone-marl cycles in the Toarcian of the northern and east-central part of the Iberian subplate (Spain). Geo- Research Forum 6, 301-310.

Gómez, J.J., Goy, A., 2005. Late Triassic and Early Jurassic palaeogeographic evolution and depositional cycles of the Western Tethys Iberian platform system (Eastern Spain). Palaeogeography, Palaeoclimatology, Palaeoecology 222, 77-94.

Gómez, J.J., Goy, A., 2010. Early Toarcian (Early Jurassic) mass extinction linked to warming in Northern and Central Spain. Comparison with other sections of West- ern Europe. Earth Science Frontiers (Special issue) 17, 374-375.

Gómez, J.J., Goy, A., 2011. Warming-driven mass extinction in the Early Toarcian (Early Jurassic) of northern and central Spain. Correlation with other time- equivalent European sections. Palaeogeography, Palaeoclimatology, Palaeoecology 306, 176-195.

Gómez, J.J., Goy, A., Canales, M.L., 2008. Seawater temperature and carbon isotope var- iations in belemnites linked to mass extinction during the Toarcian (Early Jurassic) in Central and Northern Spain. Comparison with other European sections. Pal- aeogeography, Palaeoclimatology, Palaeoecology 258, 28-58.

Goy, G., Noël, D., Busson, G., 1979. Les conditions de sedimentation des schistes-carton (Toarcien inf.) du Basin de Paris deduites de l'etude des nannofossiles calcaires et des diagraphies. Documents du Laboratoire de Géologie de la Faculté des Sciences de Lyon 75, 33-57. 
Goy, A., Comas-Rengifo, M.J., Arias, C., Gómez, J.J., González, J.A., Herrero, C., Palencia, A., Perilli, N., Rodrigo, A., 2006. The Pliensbachian-Toarcian boundary in the Almonacid de la Cuba section (Iberian Range, Spain). Volumina Jurassica 4, 164-166.

Gröcke, D.R., Rimmer, S.M., Yoksoulian, L.E., Cairncross, B., Tsikos, H., van Hunen, J., 2009. No evidence for thermogenic release in coal from the Karoo-Ferrar large ig- neous province. Earth and Planetary Science Letters 277, 204-212.

Grün, W., Zweili, F., 1980. Das Kalkige Nannoplankton der Dogger-Malm-Grnze im Berner Jura bei Liesberg (Schweiz). Jahrbuch der Geologischen Bundesanstalt 123, 231-341. Grün, W., Prins, B. Zweili, F., 1974. Coccolithophoriden aus dem Lias epsilon von Holzmaden (Deutschland). Abhandlungen 147, 294-328.

Neues Jahrbuch für Geologie und Paläontologie,

Guex, J., Morard, A., Bartolini, A., Morettini, E., 2001. Découverte d'une importante lacune stratigraphique à la limite Domérien-Toarcien: implications paléo-océnographiques. Bulletin Société vaudoise des Sciences naturelles $87,277-284$

Hallam, A., 1961. Cyclothems, transgressions and faunal change in the Lias of north- west Europe. Transactions of the Edinburgh Geological Society 18, 132-174.

Hallam, A., 1981. A revised sea-level curve for the early Jurassic. Journal of the Geolog- ical Society, London 138, 735-743.

Hallam, A., 1997. Estimates of the amount and rate of sea-level change across the RhaetianHettangian and Pliensbachian-Toarcian boundaries (latest Triassic and Early Jurassic). Journal of the Geological Society, London 154, 773-779.

Hallam, A., Wignall, P.B., 1999. Mass extinctions and sea-level changes. Earth-Science Reviews $48,217-250$.

Haq, B.U., 1978. Calcareous nannoplankton. In: Haq, B.U., Boersma, A. (Eds.), Introduc- tion to Marine Micropaleontology. Elsevier, New York, pp. 79-107.

Haq, B.U., Premoli-Silva, I., Lohmann, G.P., 1977. Calcareous plankton paleogeographic evidence for major climatic fluctuations in the early Cenozoic Atlantic Ocean. Journal of Geophysical Research 82, 3861-3876.

Hardenbol, J., Thierry, J., Farley, M.B., Jacquin, Th., de Graciansky, P.C., Vail, P.R., 1998. Mesozoic and Cenozoic sequence chronostratigraphy framework of European ba- sins. Jurassic chronostratigraphy. In: De Graciansky, P.C., Hardenbol, J., Jacquin, Th., Vail, P. (Eds.), Mesozoic and Cenozoic Sequence Stratigraphy of European Ba- sins: SEMP Special Publication, vol. 60, pp. 3-13.

Harries, P.J., Little, C.T.S., 1999. The Early Toarcian (Early Jurassic) and the Cen- omanianTuronian (Late Cretaceous) mass extinctions: similarities and contrasts. Palaeogeography, Palaeoclimatology, Palaeoecology 154, 39-66.

Hart, M.B., Hylton, M.D., Smart, C.W., 2010. Foraminiferal response to the Toarcian ex- tinction event. Earth Science Frontiers (Special issue) 17, 369-370.

Hay, W.W., Mohler, H.P., 1967. Calcareous nannoplankton from early Tertiary rocks at Pont Labau, France, and Paleocene-Early Eocene correlations. Journal of Paleontol- ogy 41, 1505-1541.

Hermoso, M., Le Callonnec, L., Minoletti, F., Renard, M., Hesselbo, S.P., 2009. Expression of the Early Toarcian negative carbon-isotope excursion in separated carbonate microfractions (Jurassic, Paris Basin). Earth and Planetary Science Letters 277, 194-203. Hesselbo, S.P., Pieñkowski, G., 2011. Stepwise atmospheric carbon-isotope excursion during the Toarcian Oceanic Anoxic Event (Early Planetary Science Letters 301, 365-372. Jurassic, Polish Basin). Earth and

Hesselbo, S.P., Gröcke, D.R., Jenkyns, H.C., Bjerrum, C.J., Farrimond, P., Morgans Bell, H.S. Green, O.R., 2000. Massive dissociation of gas hydrate during a Jurassic ocean- ic anoxic event. Nature 406, 392-395.

Hesselbo, S.P., Jenkyns, H.C., Duarte, L.V., Oliveira, L.C.V., 2007. Carbon-isotope record of the Early Jurassic (Toarcian) oceanic anoxic event from fossil wood and marine car- bonate (Lusitanian Basin,

Portugal). Earth and Planetary Science Letters 253, 455-470. Hiramatsu, C. De Deckker, P., 1997. The calcareous nannoplankton assemblages of sur- face sediments in the Tasman and Coral Seas.

Palaeoecology 131, 257-285.

Palaeogeography, Palaeoclimatology,

Howarth, M.K., 1973. The stratigraphy and ammonite fauna of the Upper Liassic Grey Shales of the Yorkshire coast. Bulletin of the British Museum - Natural History 24, 235-277.

Howarth, M.K., 1992. The ammonite family hildoceratidae in the Lower Jurassic of Britain. Part one. Monograph of the Palaeontographical Society London 2, 107-200.

Hylton, M.D., Hart, M.B., 2000. Benthic foraminiferal response to Pliensbachian- Toarcian (Lower Jurassic) sea-level change and oceanic anoxia in NW Europe. Geo- Research Forum 6, 455-462.

Izumi, K., Tanabe, K., 2010. The Early Toarcian OAE in Northeastern Tethys from the viewpoint of the bioturbation (Toyora area, West Japan). Earth Science Frontiers (Special issue) 17, 357-358.

Jenkyns, H.C., 1988. The Early Toarcian (Jurassic) anoxic event: stratigraphic, sedimen- tary and geochemical evidence. American Journal of Sciences 288, 101-151.

Jenkyns, H.C., 2003. Evidence for rapid climate change in the Mesozoic-Palaeogene greenhouse world. Philosophical Transactions of the Royal Society of London A 361, 1885-1916

Jenkyns, H.C., Clayton, C.J., 1986. Black shales and carbon isotopes in pelagic sediments from the Tethyan Lower Jurassic. Sedimentology 33, 87-106.

Jiménez, A.P., Jiménez de Cisneros, C., Rivas, P., Vera, J.A., 1996. The Early Toarcian an- oxic event in the Westernmost Tethys (Subbetic): paleogeographic and paleo- biogeographic significance. The Journal of Geology 104, 399-416.

Kauffman, E.G., Erwin, D.H., 1995. Surviving mass extinctions. Geotimes 14, 14-17. Kearey, P.,

2001. The New Penguin Dictionary of Geology. Penguin, London.

Kemp, D.B., Coe, A.L., Cohen, A.S., Schwark, L., 2005. Astronomical pacing of methane release in the Early Jurassic period. Nature 437, 396-399.

Kidder, D.L., Worsley, T.R., 2004. Causes and consequences of extreme Permo-Triassic warming to globally equable climate and relation Permo-Triassic extinction and recovery. Palaeogeography, Palaeoclimatology, Palaeoecology 203, 207-237.

Kilham, P., Kilham, S.S., 1980. The evolutionary ecology of phytoplankton. In: Morris, I. (Ed.), The Physiological Ecology of Phytoplankton. Blackwell, Oxford, pp. 571-597.
Küspert, W., 1982. Environmental changes during oil shale deposition as deduced from stable isotope ratios. In: Einsele, G., Seilacher, A. (Eds.), Cyclic and Event Stratifica- tion. Springer, New York, pp. 482-501.

Legge, H.L., Mutterlose, J., Arz, H.W., Paetzold, J., 2008. Nannoplankton successions in the northern Red Sea during the last glaciation (60 to $14.5 \mathrm{ka} \mathrm{BP}$ ): reactions to cli- mate change. Earth and Planetary Science Letters 270, 271-279.

Little, C.T.S., Benton, M.J., 1995. Early Jurassic mass extinction: a global long-term event. Geology 23, 495-498.

Littler, K., Hesselbo, S.P., Jenkyns, H.C., 2010. A carbon-isotope perturbation at the Pliensbachian-Toarcian boundary: evidence from the Lias Group, NE England. Geo- logical Magazine 147, 181-192.

Lohmann, H., 1902. Die Coccolithophoridae, eine Monographie der Coccolithen bil- denden Flagellaten, zugleich ein Beitrag zur Kenntnis des Mittelmeerauftriebs. Archiv für Protistenkunde 1, 89-165.

Macchioni, F., 2002. Myths and legends in the correlation between the Boreal and Tethys Implications on the dating of the oceanic anoxic event in Lower Toarcian age OAE and on the mass extinction of the Lower Toarcian. Geobios 35, 150-164.

Mailliot, S., Mattioli, E., Guex, J., Pittet, B., 2006. The Early Toarcian anoxia, a synchro- nous even in the Western Tethys? An approach by quantitative biochronology (Unitary Associations), applied on calcareous nannofossils. Palaeogeography, Pal- aeoclimatology, Palaeoecology 240, 562-586.

Mailliot, S., Mattioli, E., Bartolini, A., Baudin, F., Pittet, B., Guex, J., 2009. Late Pliensbachian- Early Toarcian (Early Jurassic) environmental changes in an epicontinental basin of NW Europ (Causses area, central France): a micropaleontological and geochemical approach Palaeogeography, Palaeoclimatology, Palaeoecology 273, 346-364.

Mattioli, E., 1997. Nannoplankton productivity and diagenesis in the rhythmically bed- ded Toarcian-Aalenian Fiuminata section (Umbria-Marche Apennine, central Italy). Palaeogeography, Palaeoclimatology, Palaeoecology 130, 113-133.

Mattioli, E., Erba, E., 1999. Synthesis of calcareous nannofossil events in Tethyan Lower and Middle Jurassic successions. Rivista Italiana di Paleontologia e Stratigrafia 105, 343-376.

Mattioli, E., Pittet, B., 2002. Contribution of calcareous nannoplankton to carbonate de- position: a new approach applied to the Lower Jurassic of central Italy. Marine Mi- cropaleontology 45, $175-190$.

Mattioli, E., Pittet, B., 2004. Spatial and temporal distribution of calcareous nannofossils along a proximal-distal transect in the Lower Jurassic of the Umbria Marche Basin (central Italy). Palaeogeography, Palaeoclimatology, Palaeoecology 205, 295-316. Mattioli, E., Pittet, B., Young, J.R., Bown, P.R., 2004a. Biometric analysis of Pliensbachian- Toarcian (Lower Jurassic) coccoliths of the family Biscutaceae: intra- and interspecific variability versus palaeoenvironmental influence. $5-27$. Marine Micropaleontology 52,

Mattioli, E., Pittet, B., Bucefalo Palliani, R., Röhl, H.-J., Schmid-Röhl, A., Morettini, E., 2004b. Phytoplankton evidence of the timing and correlation of palaeoceanographical changes during the Early Toarcian oceanic anoxic event (Early Jurassic). Journal of the Geological Society, London 161, 685-693.

Mattioli, E., Pittet, B., Suan, G., Mailliot, S., 2008. Calcareous nannoplankton changes across the Early Toarcian oceanic anoxic event in the western Tethys. Paleo- ceanography 23, PA3208, http://dx.doi.org/10.1029/2007PA001435.

Mattioli, E., Pittet, B., Petitperre, L., Mailliot, S., 2009. Dramatic decrease of pelagic carbon- ate production by nannoplankton across the Early Toarcian anoxic event (T-OAE). Global and Planetary Change 65, 134-145.

McArthur, J.M., 2007. Comment on "carbon-isotope record of the Early Jurassic (Toarcian) oceanic anoxic event from fossil wood and marine carbonate (Lusitani- an Basin, Portugal)", by Hesselbo, S.P., Jenkyns, H.C., Duarte, L.V., Oliveira, L.C.V. Earth and Planetary Science Letters 259, 634-639.

McArthur, J.M., Donovan, D.T., Thirlwall, M.F., Fouke, B.W., Mattey, D., 2000. Strontium isotope profile of the Early Toarcian (Jurassic) oceanic anoxic event, the duration of ammonite biozones, and belemnite palaeotemperatures. Earth and Planetary Sci- ence Letters 179, 269 285.

McArthur, J.M., Doyle, P., Leng, M.J., Reeves, K., Williams, T., García-Sanchez, R., Howart, R.J., 2007. Testing palaeo-environmental proxies in Jurassic belemnites: $\mathrm{Mg} / \mathrm{Ca}, \mathrm{Sr} / \mathrm{Ca}, \mathrm{Na} / \mathrm{Ca}, \delta^{18} \mathrm{O}$ and $\delta^{13} \mathrm{C}$. Palaeogeography, Palaeoclimatology, Palaeoecology 252, 464-480.

McArthur, J.M., Algeo, T.J., van de Schootbrugge, B., Li, Q., Howart, R.J., 2008. Basinal re- striction, black shales, Re-Os dating, and Early Toarcian (Jurassic) oceanic anoxic event. Paleoceanography 23, PA4217, http://dx.doi.org/10.1092/2008PA001607.

McElwain, J.C., Wade-Murphy, J., Hesselbo, S.P., 2005. Changes in the carbon dioxide dur- ing an anoxic event linked to intrusion into Godwana coals. Nature 435, 479-482.

Medd, A.W., 1971. Some Middle and Upper Jurassic Coccolithophoridae from England and France. Institute of Geological Sciences, London, England, pp. 821-845.

Metodiev, L., Koleva-Rekalova, E., 2008. Stable isotope records $\left(\delta^{18} \mathrm{O}\right.$ and $\left.\delta^{13} \mathrm{C}\right)$ of Lower-Middle Jurassic belemnites from the Western Balkan mountains (Bulgaria): palaeoenvironmental application. Applied Geochemistry 23, 2845-2856.

Molfino, B., McIntyre, A., 1990. Precessional forcing of nutricline dynamics in the equa- toria Atlantic. Science 249, 766-769.

Monaco, P., 1995. Relationships between trace-fossil communities and substrate char- acteristics in some Jurassic pelagic deposits in the Umbria-Marche basin, Central Italy. Geobios 28, 299311.

Nikitenko, B.L., Shurygin, B.N., 1994. Lower Toarcian black shales and Pliensbachian-- Toarcian crisis of the biota of Siberian Paleoseas. In: Thurston, D.K., Fujita, K. (Eds.), 1992 Proceeding of the International Conference on Artic Margins, U.S. Department of the Interior, Minerals Management Service, Alaska Outer Continental Shelf Region, pp. 39-45 (Anchorage, USA).

Nocchi, M., Bartolini, A., 1994. Investigation on Late Domerian-Early Toarcian Lagenina and Glomospirella assemblages in the Umbria-Marche Basin (Central Italy). Geobios 17, 689-699. 
Noël, D., 1965. Sur les coccolithes du Jurassiques européen et d'Afrique du Nord. : Essai de classification des Coccolithes fossiles, VII. Centre National de la Reserche scientifique, CNRS, Paris, pp. 1-209.

Okada, H., Honjo, S., 1973. The distribution of oceanic coccolithophorids in the Pacific. Deep-Sea Research 20, 355-374.

Okada, H., Wells, P., 1997. Late Quaternary nannofossil indicators of climate change in two deepsea cores associated with the Leeuwin Current off Western Australia. Palaeogeography, Palaeoclimatology, Palaeoecology 131, 413-432.

Osete, M.L., Villalaín, J.J., Osete, C., Gialanella, P.R., 2000. Evolución de Iberia durante el Jurásico a partir de datos paleomagnéticos. Geotemas 1, 117-119.

Osete, M.L., Gómez, J.J., Pavón-Carrasco, F.J., Villalaín, J.J., Palencia, A., Ruiz-Martinez, V.C., Heller, F., 2011. The evolution of Iberia during the Jurassic from palaeomagnetic data Tectonophysics 502, 105-120.

Page, K.N., 2003. The Lower Jurassic of Europe: its subdivision and correlation. Geolog- ical Survey of Denmark and Greenland Bulletin 1, 23-59.

Page, K.N., 2004. A sequence of biohorizons for the Subboreal Province Lower Toarcian in northern Britain and their correlation with a Submediterranean standard. Rivista Italiana di Paleontologia e Stratigrafia 110, 109-114.

Pálfy, J., Smith, P.L., 2000. Synchrony between Early Jurassic extinction, oceanic anoxic event, and the Karoo-Ferrar flood basalt volcanism. Geology 28, 747-750.

Pearce, C.R., Cohen, A.S., Coe, A.L., Burton, K.W., 2006. Changes in the extent of marine an- oxia during the Early Jurassic: evidence from molybdenum isotopes. Goldschmidt Conference Abstracts, http://dx.doi.org/10.1016/j.gca.06.1415.

Perilli, N., Comas-Rengifo, M.J., Goy, A., 2004. Calibration of the Pliensbachian-Toarcian calcareous nannofossil zone boundaries based on Ammonites (Basque-Cantabrian area, Spain). Rivista Italiana di Paleontologia e Stratigrafia 110, 97-107.

Pittet, B., Mattioli, E., 2002. The carbonate signal and calcareous nannofossil distribu- tion in an Upper Jurassic section (Balingen-Tieringen, Late Oxfordian, southern Germany) Palaeogeography, Palaeoclimatology, Palaeoecology 179, 71-96.

Prauss, M., Ligouis, B., Lutterbacher, H., 1991. Organic matter and palynomorphs in the "Posidonienschifers" (Toarcian, Lower Jurassic) of southern Germany. In: Tyson, R.V., Pearson, T.H. (Eds.), Modern and Ancient Continental Shelf Anoxia: Geological Society Special Publication, 58, pp. 335-351.

Price, G.D., 1999. The evidence of polar ice during the Mesozoic. Earth-Science Reviews 48, 183210.

Price, G.D., Twitchett, R.J., Smale, C., Marks, V., 2009. Isotopic analysis of the life history of the enigmatic squid Spirula spirula, with implications for studies of fossil cepha- lopods. Palaios 24, 273-279.

Prins, B., 1969. Evolution and stratigraphy of coccolothinids from the Lower and Middle Lias. Proceeding on First International Conference on Planktonic Microfossils 2, 547-558.

Reggiani, L., Mattioli, E., Pittet, B., Duarte, L.V., Veiga de Oliveira, L.C., Comas-Rengifo, M.J., 2010 Pliensbachian (Early Jurassic) calcareous nannofossils from the Peniche section (Lusitanian Basin, Portugal): a clue for palaeoenvironmental reconstruc- tions. Marine Micropaleontology $75,1-16$

Rexfort, A., Mutterlose, J., 2009. The role of biogeography and ecology on the isotope signature of cuttlefishes (Cephalopoda, Sepiidae) and the impact on belemnite studies. Palaeogeography, Palaeoclimatology, Palaeoecology 244, 212-221.

Rodríguez-Tovar, F.J., Uchman, A., 2010. Ichnofabric evidence for the lack of bottom an- oxia during the Lower Toarcian oceanic anoxic event in the Fuente de la Vidriera section, Betic Cordillera, Spain. Palaios 25, 576-587.

Röhl, H.-J., Schmid-Röhl, A., Oschmann, W., Frimmel, A., Schwark, L., 2001. The Posidonia Shale (Lower Toarcian) of SW-Germany: an oxygen-depleted ecosystem controlled by sea level and palaeoclimate. Palaeogeography, Palaeoclimatology, Palaeoecology 165, 27-52.

Rood, A.P., Hay, W.W., Barnard, T., 1973. Electron microscope studies of Lower and Middle Jurassic coccoliths. Eclogae Geologicae Helvetiae 66, 365-382.

Rosales, I., Quesada, S., Robles, S., 2004. Paleotemperaturevariations of Early Jurassic seawa- ter recorded i geochemical trends of belemnites from the Basque-Cantabrian basin, northem Spain. Palaeogeography, Palaeoclimatology, Palaeoecology 203, 253-275.

Ruget, C., 1985. Les Foraminifères (Nodosariidés) du Lias de l'Europe occidentale. Doc- uments des Laboratoires de Géologie de Lyon 94, 1-272.

Sælen, G., Doyle, P., Talbot, M.R., 1996. Stable-isotope analyses of belemnite rostra from the Whitby Mudstone Fm., England: surface water conditions during deposition of a marine black shale. Palaios 11, 97-117.

Sælen, G., Tyson, R.V., Talbot, M.R., Telnæs, N., 1998. Evidence of recycling of isotopically light $\mathrm{CO}_{2}$ (aq) in stratified black shale basins: contrast between the Whitby Mud- stone and Kimmeridge Clay Formations, United Kingdom. Geology 26, 747-750.

Schmid-Röhl, A., Röhl, H.-J., Oschmann, W., Frimmel, A., Schwark, L., 2002. Palaeoenvironmental reconstruction of Lower Toarcian epicontinental black shales (Posidonia Shale, SW Germany): global versus regional control. Geobios 35, 13-20. Schouten, S., van Kaam-Peters, H.M.E, Rijpstra, W.I.C., Schoell, M., Sinninghe Damste, J.S., 2000. Effects of a oceanic anoxic event on the stable carbon isotopic composition of Early Toarcian carbon. American Journal of Sciences 300, 1-22.

Shackleton, N.J., Kennet, J.P., 1975. Paleotemperature history of the Cenozoic and the ini- tiation of Antartic glaciation: oxygen and carbon isotope analysis in DSDP sites 277, 279 and 281. In: Kennet, J.P., Houtz, R.E., et al. (Eds.), Initial Reports of the Deep Sea Drilling Projects 29. Government Printing Office, Washington, U.S, pp. 743-756.
Shannon, C.E., Weaver, W., 1949. The Mathematical Theory of Communication. Univer- sity of Illinois Press, Urbana. 125 pp.

Sheldon, E., Ineson, J., Bown, P., 2010. Late Maastrichtian warming in the Boreal Realm; calcareous nannofossil evidence from Denmark. Palaeogeography, Palaeoclimatology, Palaeoecology 295, 55-75.

Sinaci, M., Toker, V., 2009. Nannoplankton biostratigraphy of the Selandian-Ypresian Güney Formation (Ulukisla Basin) and sea-water temperature changes in this period. Bulletin of the Mineral Research and Exploration Institute of Turkey 139, 17-31.

Stampfli, G.M., Borel, G.D., 2002. A plate tectonic model for the Paleozoic and Mesozoic constrained by dynamic plate boundaries and restored synthetic ocean isochrones. Earth and Planetary Science Letters 196, 17-33.

Stampfli, G.M., Borel, G.D., 2004. The TRANSMED transects in space and time: con- straints on the paleotectonic evolution of the Mediterranean domain. In: Cavazza, W., Roure, F.M., Spakman, W., Stampfli, G.M., Ziegler, P.A. (Eds.), The TRANSMED Atlas-The Mediterraean Region from Crust to Mantle. Springer, Berlin Heidelberg New York, pp. 53-80. CD-ROM

Stradner, V.H., 1961. Vorkommen von Nannofossilien im Mesozoikum und Alttertiär. Erdoel Zeitschrift für Bohr- und Fördertechnik 77, 77-88.

Suan, G., Mattioli, E., Pittet, B., Mailliot, S., Lécuyer, C., 2008. Evidence for major envi- ronmental perturbation prior to and during the Toarcian (Early Jurassic) oceanic anoxic event from the $\begin{array}{llll}\text { Lusitanian } & \text { Basin, } & \text { Portugal. } & \text { Paleoceanography }\end{array}$ http://dx.doi.org/10.1029/2007PA001459.

Suan, G., Mattioli, E., Pittet, B., Lécuyer, C., Suchéras-Marx, B., Duarte, L.V., Philippe, M., Reggiani, L., Martineau, F., 2010. Secular environmental precursors to Early Toarcian (Jurassic) extreme climate changes. Earth and Planetary Science Letters 290, 448-458. Summons, R.E., Hope, J.M., Swart, R., Walter, M.R., 2008. Origin of Nama Basin bitumen seeps: petroleum derived from Permian soutwestern Gondwana. Organic Geochemistry 39, 589-607.

lacustrine source rock traversing nsen, H., Planke, S., Chevallier, L., Malthe-Sorenssen, A., Corfu, F., Jamtveit, B., 2007. Hydrothermal venting of greenhouse gases triggering Early Jurassic global warming. Earth and Planetary Science Letters 256 (4), 554-566.

Tremolada, F., van de Schootbrugge, B., Erba, E., 2005. Early Jurassic schizosphaerellid crisis in Cantabria, Spain: implications for calcification rates and phytoplankton evolution across the Toarcian anoxic events. Paleoceanography 20, 1-11.

Tremolada, F., Erba, E., van de schootbrugge, B., Mattioli, E., 2006a. Calcareous nannofossil changes during the late Callovian-early Oxfordian cooling phase. Ma- rine Micropaleontology 59, 197-209.

Tremolada, F., Bornemann, A., Bralower, T.J., Koeberl, C., van de Schootbrugge, B., 2006b. Paleoceanographic changes across the Jurassic/Cretaceous boundary: the calcareous phytoplankton response. Earth and Planetary Science Letters 241, 361-371.

Twitchett, R.J., 2006. The palaeoclimatology, palaeoecology and palaeoenvironmental analysis of mass extinction events. Palaeogeography, Palaeoclimatology, Palaeo- ecology 232, 190213

Valenzuela, M., 1988. Estratigrafía, sedimentología y paleogeografía del Jurásico de As- turias. Unpubl. Ph.D. Thesis, University of Oviedo. Oviedo, Spain.

Valenzuela, M., García-Ramos, J.C., Suárez de Centi, C., 1986. The Jurassic sedimentation in Asturias (N Spain). Trabajos de Geología 16, 121-132.

van Breugel, Y., Schouten, S., Baas, M., Mattioli, E., Sinninghe Damsté, J.S., 2006. Iso- renieratane record in black shales from the Paris Basin, France: constraints on recycling of respired $\mathrm{CO}_{2}$ as a mechanism for negative carbon isotope shifts during the Toarcian oceanic anoxic event. Paleoceanography 21, PA4220, http:// dx.doi.org/10.1029/2006PA001305.

van de Schootbrugge, B., McArthur, J.M., Bailey, T R., Rosenthal, Y., Wright, J.D., Miller, K.G., 2005. Toarcian oceanic anoxic event: an assessment of global causes using belemnite C isotope records. Paleoceanography 20, PA3008, http://dx.doi.org/ 10.1029/2004PA001102.

Vörös, A., 2002. Victims of the Early Toarcian anoxic event: the radiation and extinction of Jurassic Koninckinidae (Brachiopoda). Lethaia 35, 345-357.

Walsworth-Bell, E. B., 2001. Jurassic calcareous nannofossils and environmental cycles. Unpubl. Ph.D. Thesis, University College of London. London, United Kingdom.

Walther, G.R., Post, E., Convey, P., Menzels, A., Parmesan, C., Beebee, T.J.C., Fromentin, J.M., 2002. Ecological response to recent climate change. Nature 416, 389-395.

Wiegand, G.E., 1984. Two new genera of calcareous nannofossils from the Lower Juras- sic. Journal of Paleontology 58, 1151-1155.

Wignall, P.B., 2001. Large igneous provinces and mass extinctions. Earth-Science Re- views 53, $1-33$.

Wignall, P.B., Newton, R.J., Little, C.T.S., 2005. The timing of paleoenvironmental change and causeand-effects relationships during the Early Jurassic mass extinction in Europe. American Journal of Sciences 305, 1014-1032.

Wright, E.K., 1987. Stratification and paleocirculation of the Late Cretaceous Western Interior Seaway of North America. Geological Society of American Bulletin 99, 480-490.

Ziegler, P.A., 1990. Geological atlas of western and central Europe. Shell Interna- tional Petroleum. Maatschappij B.V. Geological Society Publishing House, Bath. 1-239 pp. 